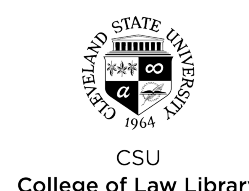

Cleveland State University

College of Law Library EngagedScholarship@CSU

\title{
The Taxation of Income Available for Discretionary Use
}

Deborah A. Geier

Cleveland State University, d.geier@csuohio.edu

Follow this and additional works at: https://engagedscholarship.csuohio.edu/fac_articles

Part of the Tax Law Commons

How does access to this work benefit you? Let us know!

\section{Original Citation}

Deborah A. Geier, The Taxation of Income Available for Discretionary Use, 25 Virginia Tax Review 765 (Winter 2006)

This Article is brought to you for free and open access by the Faculty Scholarship at EngagedScholarship@CSU. It has been accepted for inclusion in Law Faculty Articles and Essays by an authorized administrator of EngagedScholarship@CSU. For more information, please contact research.services@law.csuohio.edu. 


\section{HEINONLINE}

Citation: 25 Va. Tax Rev. 765 2005-2006

Content downloaded/printed from

HeinOnline (http://heinonline.org)

Wed Sep 26 15:54:42 2012

-- Your use of this HeinOnline PDF indicates your acceptance of HeinOnline's Terms and Conditions of the license agreement available at http://heinonline.org/HOL/License

-- The search text of this PDF is generated from uncorrected OCR text.

-- To obtain permission to use this article beyond the scope of your HeinOnline license, please use:

https://www.copyright.com/ccc/basicSearch.do?

\&operation $=$ go\&search Type $=0$

\&lastSearch $=$ simple\&all=on\&titleOrStdNo=0735-9004 


\title{
THE TAXATION OF INCOME AVAILABLE FOR DISCRETIONARY USE
}

\author{
Deborah A. Geier
}

While the signature tax policy tension of the last two decades (at least) has been whether the federal tax base ought to reach "income" or only "consumption," there is, I believe, a persuasive argument that this debate misses the point. I think the key to understanding the theoretical construct underlying our desires for the "ideal" tax base - as well as the key to improving current law - is that we wish to protect from taxation wealth accessions spent on "nondiscretionary" consumption or saved for future nondiscretionary consumption. This distinction between "discretionary" and "nondiscretionary" income, first explored several decades ago by Canada's Royal Commission on Taxation in connection with a progressive rate structure, has significant explanatory force with respect to several key provisions in our current tax base and offers a promising route to significant reform.

\section{TABLE OF CONTENTS}

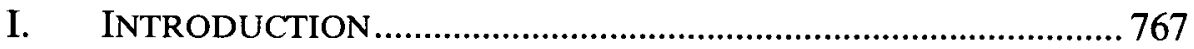

II. EVIDENCE OF OUR CONCEPTION OF THE "IDEAL" TAX BASE DRAWN FROM CURRENT LAW 768

III. THE ROYAL COMMISSION ON TAXATION 774

- Leon M. \& Gloria Plevin Professor of Law, Cleveland-Marshall College of Law, Cleveland State University. I would like to thank the participants at the Tax Law Colloquia at Northwestern University Law School, particularly David Cameron and Charlotte Crane, and at the University of Michigan Tax Law and Policy Workshop, particularly Reuven Avi-Yonah, David Hasen, Jim Hines, and Mike McIntyre, for their helpful comments. Of course, they should be held harmless with respect to the results; any errors (in both fact and judgment) remain mine. 
IV. THE CONTENTS OF THE NONDISCRETIONARY DEDUCTION.. 778

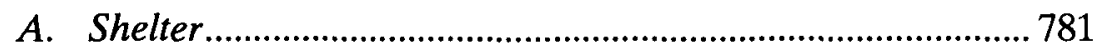

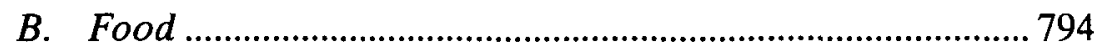

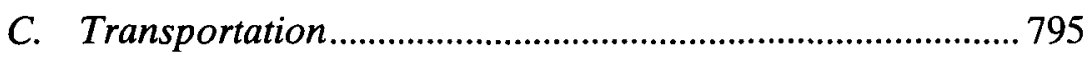

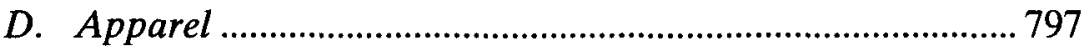

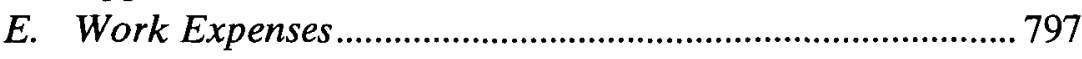

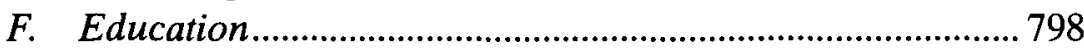

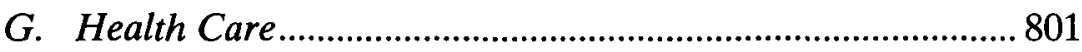

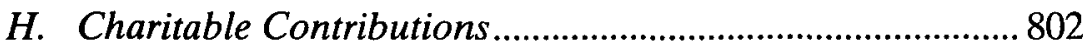

I. Retirement Savings (Outside Social Security) .................... 803

J. State and Local Income and Sales Taxes and Federal

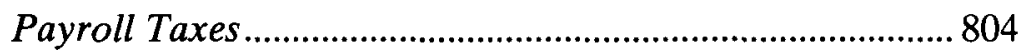

K. Final Thoughs on the Nondiscretionary Deduction ...........806

V. THE TAXATION OF CAPITAL INCOME .......................................... 810

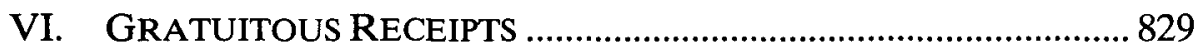

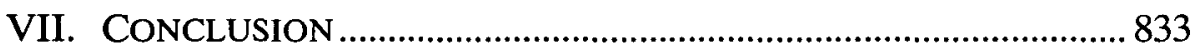

The average two-income family earns far more today than did the single-breadwinner family of a generation ago. And yet, once they have paid the mortgage, the car payments, the taxes, the health insurance, and the day-care bills, today's dualincome families have less discretionary income - and less money to put away for a rainy day - than the single-income family of a generation ago.

\section{Elizabeth Warren \& Amelia Warren Tyagi ${ }^{1}$}

I conclude that the primary tax reform agenda is not centered on enacting some pure form of taxation.

C. Eugene Steuerle ${ }^{2}$

1 Elizabeth Warren \& Amelia Warren Tyagl, The.Two-Income Trap: WHy Middle-Class Mothers AND FATHERs ARE GoING BRoKe 8 (2003) (emphasis in original). 


\section{INTRODUCTION}

The signature tax policy tension of the last two decades (at least) has been whether the federal tax base ought to reach "income" or only "consumption." A close examination of the contours of the current tax base in Part II, however, provides convincing evidence that the true value underlying our conception of the "ideal" tax base is that wealth accessions that are not fairly available for contribution to the fisc should be protected from taxation, while wealth accessions that are fairly available should be currently taxed. Wealth accessions may be considered not fairly available for contribution to the fisc if either spent on current nondiscretionary consumption or placed in savings to fund future nondiscretionary consumption. Wealth accessions may be considered fair game to the extent that they fund current discretionary consumption or fund savings for future discretionary consumption.

The importance of the distinction between "discretionary" and "nondiscretionary" income to tax policy was explicitly recognized in a 1966 report written by Canada's Royal Commission on Taxation. Although that Commission raised the distinction in defending a progressive rate structure, as Part III shows, the idea has persuasive force in defining the tax base, as well. Part IV examines the 2000-2001 Consumer Expenditure Survey (published in 2003) in the course of discussing the Nondiscretionary Deduction that I propose as a replacement for the Standard Deduction, the Personal and Dependent Exemption Deductions, the Child Tax Credit, the Qualified Residence Interest Deduction, the Deduction for State and Local Income and Property Taxes, and perhaps the Dependent Care Credit and the Hope and Lifetime Learning Credits. As further explored below, the Nondiscretionary Income Deduction would be keyed to median outlays rather than the actual outlays of each taxpayer, although the amount of the deduction would be derived under a "check-the-box" format that takes into account relevant taxpayer "status" criteria (such as household size, whether the taxpayer owns or rents a home, perhaps whether the taxpayer or dependent is a fulltime student in higher education, etc.). While simplification would be a welcome side effect to this approach, it is based in principle - in a rationalization of the implicit values underlying current law - and not

2 C. Eugene Steuerle, Contemporary U.S. Tax Policy 235 (2004).

${ }^{3}$ See 3 Report of the Royal Commission on TAXation 1-24 [hereinafter ROYAL COMMISSION REPORT]. 
on a desire for simplicity for its own sake.

If "discretionary" income is more fairly taxed than "nondiscretionary income," the reduced tax rate for net capital gain and dividend income, as well as the blanket exclusion for home sale gain, are indefensible. I discuss the latter in Part IV in connection with shelter costs, and the former in Part V.

Moreover, as described in Part VI, the values espoused in this article also imply that large gratuitous receipts (above an administratively feasible exemption amount of, say, $\$ 25,000$ per year), whether received as an inter vivos receipt or at death of the transferor, should be included in the recipient's tax base. All included in-kind receipts could then take a fresh, fair market value basis, as under current section 1014 (section 1015 would be retained only for in-kind receipts excluded under the de minimis rule), and the wealth transfer taxes (the estate, gift, and generation-skipping tax regimes) could be permanently repealed. Finally, with a properly tailored tax base, the Alternative Minimum Tax should be repealed.

\section{EVIDENCE OF OUR CONCEPTION OF THE "IDEAL" TAX BASE DRAWN FROM CURRENT LAW}

A pure income tax generally taxes both amounts spent on current consumption and amounts saved. A pure consumption tax (such as a cash-flow consumption tax, a retail sales tax, or a value-added tax), in contrast, taxes only amounts spent on consumption, deferring tax on amounts saved until withdrawn from investment and spent on consumption. Another conception is to say that an income tax reaches both returns to labor and returns to capital, while a consumption tax generally reaches only returns to labor. ${ }^{4}$ That is to say, with identical investment returns and tax rates, a wage tax (a tax on only labor income) can reach the same end result as a consumption $\operatorname{tax}^{5}$

${ }^{4}$ These descriptions are not free of controversy. Consumption tax proponents would argue that an income tax taxes capital returns twice and consumption outlays only once, while a consumption tax taxes capital returns only once, putting them on equal footing with consumption expenditures. The income tax proponent would reply that this argument requires "collapsing" time in a way that ignores taxpaying capacity as time progresses. These arguments are not the focus of this Article, but the reader interested in a general introductory description of these differing conceptions can see Joseph M. Dodge, J. Clifton Fleming, Jr. \& Deborah A. Geier, Federal InCOME TAX: Doctrine, STRUCTURE, AND POLICY 72-76 (3d ed. 2004).

5 See id. at $72-73$. 
At the individual level, the current Internal Revenue Code (Code) (payroll taxes aside, for the moment) incorporates an income tax base with numerous consumption tax components - provisions that allow either immediate deduction of a nonconsumption capital expenditure (as under a cash-flow consumption tax) or exclusion of the returns to capital (as under a wage tax). A few of the most noteworthy cash-flow consumption tax components include the deferral of contributions to qualified pension plans, ${ }^{6}$ regular Individual Retirement Accounts (IRAs), ${ }^{7}$ and Health Savings Accounts; ${ }^{8}$ the deferral of the inside buildup on life insurance; the deferral of gain on most other assets under the "realization requirement"; expensing of certain long-lived business assets;" and the accelerated rate of regular depreciation for many assets. ${ }^{10}$ These are consistent with a cash-flow consumption tax because they effectively allow full or partial deduction of an investment prior to the time the investment is lost or consumed. A few of the most noteworthy wage tax features include the exclusion of most home sale gain, ${ }^{11}$ state and local bond interest, ${ }^{12}$ Roth IRA returns, ${ }^{13}$ and life insurance proceeds paid by reason of the death of the insured. ${ }^{14}$ A more subtle wage tax feature is the reduced tax rate, at the individual level, of most capital gain and dividend income. ${ }^{15}$ (A pure wage tax would apply a zero rate.)

The hybrid nature of the current Code is often said to be the chief indicator that it is theoretically dysfunctional (as well as inexcusably complex on an administrative level). The confluence of income and consumption tax provisions seems to indicate that we simply cannot make up our minds which base is "best," and thus we have enacted a hodgepodge of provisions from both worlds, picking and choosing here and there from both menus. But there is a persuasive argument

${ }^{6}$ See I.R.C. $\S \S 401-420$.

7 See I.R.C. $\$ 408$.

${ }^{8}$ See I.R.C. $\$ 223$. Actually, Health Savings Accounts provide better than consumption tax treatment to the extent withdrawn amounts are spent on qualified medical expenses; the contribution to the account is deductible and the withdrawal is excludable.

9 See I.R.C. § 179.

${ }^{10}$ See I.R.C. $\$ 168(\mathrm{a})$.

"See I.R.C. \$ 121.

12 See I.R.C. $\$ 103$.

13 See I.R.C. § 408A.

${ }^{14}$ See I.R.C. $\$ 101$.

15 See I.R.C. $\$ 1(\mathrm{~h})$. 
that this debate misses the point. The key to understanding the theoretical construct underlying our conception of an "ideal" tax base - as well as the key to improving current law - is that we wish to protect from taxation what I shall call "nondiscretionary" income, while taxing "discretionary" income (in the sense of income available for discretionary use). This distinction between "discretionary" and "nondiscretionary" income has significant explanatory force with respect to several key provisions in our current tax base. Indeed, the difference between the two kinds of income can perhaps best be explored by examples drawn from current law.

All amounts spent on consumption would be taxed under either a theoretically pure income or consumption tax base. Yet, with the Standard Deduction ${ }^{16}$ and the Personal and Dependent Exemption Deductions, ${ }^{17}$ we ensure that a basic amount spent on consumption is free from tax. Why is that so, if neither an income tax nor consumption tax base demands it? The reason is that we have decided that a basic subsistence amount - even though spent on consumption, and thus taxable under either a pure income or consumption tax - ought to be free from tax because it is "nondiscretionary" and thus not fairly available for contribution to the fisc.

Taking the analysis a step further, this orientation also helps to explain the Child Tax Credit, ${ }^{18}$ a portion of the Earned Income Tax Credit, ${ }^{19}$ the Dependent Care Credit, ${ }^{20}$ and perhaps (if less perfectly) even the Hope and Lifetime Learning Credits, ${ }^{21}$ each of which also protects from taxation amounts presumably spent on consumption that would be taxed under either a pure income or a pure consumption tax. Unlike the Standard Deduction and Personal and Dependent Exemption Deductions, these go further than merely protecting bare subsistence amounts from taxation. Nevertheless, they reflect a concern that certain outlays, though consumption, are nondiscretionary in an important sense. The Child Tax Credit apparently reflects the judgment that rearing children today entails a greater expenditure than is adequately reflected in the Dependent Exemption Deductions. The Earned Income Tax Credit was

\footnotetext{
${ }^{16}$ See I.R.C. $\$ 63$.

17 See I.R.C. $\$ \S 151-152$.

${ }_{18}$ See I.R.C. \$ 24.

19 See I.R.C. \$ 32.

${ }^{20}$ See I.R.C. $\$ 21$.

${ }^{21}$ See I.R.C. § $25 \mathrm{~A}$.
} 
originally created in part to refund the low-income worker's payroll taxes. ${ }^{22}$ Since even the first dollar of wages is taxed under the payroll tax system, with no Standard Deduction or Personal and Dependent Exemption Deductions, effectively allowing a refund of these amounts is consistent with the notion that nondiscretionary income ought to be protected from tax. In other words, to this extent, the Earned Income Tax Credit is simply an extension of the idea underlying the Standard Deduction and Personal and Dependent Exemption Deductions to the payroll taxes. ${ }^{23}$ The Dependent Care Credit recognizes that child care outlays (and similar outlays for other dependents unable to care for themselves) incurred in order to allow the person to work outside the home are also nondiscretionary and thus not available for contribution to the fisc. Perhaps the most controversial members of the above list are the Hope and Lifetime Learning Credits, since the decision to engage in higher education seems to be inherently "discretionary." Yet, as study after study shows the importance of higher education to a decent job in this post-manufacturing age, ${ }^{24}$ perhaps Congress has decided that at least a certain amount spent on higher education is similarly nondiscretionary today.

Now consider the tax-preferred savings vehicles. The three main sources of savings for the middle class are retirement savings, life insurance, and home appreciation, each of which would be taxed under an income tax, but which enjoy more favorable consumption tax or wage tax treatment under current law. Lesser-used but also tax-preferred savings vehicles include the Coverdell Education Savings Accounts ${ }^{25}$ and investments in state higher education tuition savings programs. ${ }^{26}$ The amounts that can be protected from taxation

${ }^{22}$ See S. REP. No. 94-36, at 11, 33 (1975), reprinted in 1975-1 C.B. 590, 595, 603.

${ }^{23}$ To the extent that the Earned Income Tax Credit exceeds the taxpayer's payroll taxes, it is a "welfare" or transfer payment distributed via the Internal Revenue Code (Code), rather than a true "tax" provision. Professor Lawrence Zelenak notes that, in 2001 , over $80 \%$ of Earned Income Tax Dollars represented a transfer payment rather than an offset to pre-credit tax liability. See Lawrence Zelenak, The Income Tax and the Costs of Earning a Living, 56 TAX L. REV. 39, 73 (2002). The same is also true to the limited extent that the Child Tax Credit is refundable.

${ }^{24}$ See, e.g., Lexington: Minding About the Gap, ECONOMIST, June 11, 2005, at 32 (noting that "[t]he gap in income between the college-educated and the non-college educated rose from $31 \%$ in 1979 to $66 \%$ in $1997 ")$.

${ }^{25}$ See I.R.C. $\$ 530$.

${ }^{26}$ See I.R.C. \$ 529. Both the Coverdell Education Savings Accounts and section 529 qualified tuition programs provide better-than-consumption-tax treatment. Not only are the amounts contributed to the plans deductible but also withdrawals of 
under these provisions (except life insurance) are capped so that they are not available to the wealthy in full. If they were not capped and if they were not limited to the certain kinds of preferred savings that are mentioned, i.e., if we enacted a "pure" consumption tax that protected all savings from tax until consumed (or a wage tax that protected all returns from capital, including all home sale gain, from tax), the wealthy would be able to shield a much larger portion of their aggregate income from tax because the wealthy have high savings rates. $^{27}$ Indeed, the vast majority of middle-class taxpayers fail to contribute the maximum allowed to the tax-preferred savings vehicles, which implies that these limits are not set too low to accommodate most middle-class taxpayers in saving as much as they choose for retirement, etc., on a tax-preferred basis (though many commentators would urge them to save more if they could). For this reason, it is not too farfetched to say that the middle class operates under a consumption tax (except that certain nondiscretionary consumption outlays are not taxed) and the wealthy operate under an income tax (again, with certain nondiscretionary consumption outlays not taxed), with the truly poor barely taxed at all. Why do we prevent the wealthy from having all of their savings protected from current taxation?

The preferred middle-class savings vehicles can perhaps be characterized as "nondiscretionary savings," while amounts saved above the caps are deemed "discretionary" savings, because those amounts are in excess of that needed to provide a modicum of security in retirement (or for education or health care). In other words, it is not the difference between "consumption" and "savings" that matters here so much as whether the particular savings at issue should be considered "discretionary" or not.

The notion that the perennial tug-of-war between income and consumption taxation fails to capture the true underlying value that informs our choice of tax base was recognized (if inadvertently) by Elizabeth Warren and Amelia Warren Tyagi in their book The TwoIncome Trap. ${ }^{28}$ They compiled data that compare a 1973 one-earner (median) couple with a 2000 two-earner (median) couple, each with two children. Taking into consideration mortgage payments, childcare expenses, health insurance, and taxes, they show that the two-

income are tax-free to the extent used for qualifying education expenses.

${ }^{27}$ See, e.g., Christopher D. Carroll, Why Do the Rich Save So Much?, in DoES Atlas Shrug?: THE ECONOMIC CONSEQuenCES OF TAXING THE Rich 465, 476 (Joel B. Slemrod ed., 2000).

${ }^{28}$ See WARREN \& TYAGI, supra note 1. 
income couple in 2000 has $\$ 800$ less per year in discretionary income than the one-earner couple in $1973 .^{29}$ Of particular note, taxes took $24 \%$ of the 1973 median family's income while taking $33 \%$ in 2000 , even though the discretionary income of the 2000 couple was lower (though, it was lower in part due to the tax take, which is admittedly circular). ${ }^{30}$ If the 2000 couple is a single-earner family, it realizes "a 60 percent drop in discretionary income compared with its one-income counterpart of a generation ago." ${ }^{31}$

What do the authors suggest to address this situation? In part, they suggest switching from income taxation to consumption taxation, saying "[a]ll savings... should be exempt from taxes."32 But they immediately recognize that such a move would likely be regressive, since the wealthy "are the only ones with ample savings." I3 I would add the observation that most savings of the non-wealthy are already subject to consumption tax treatment. In response, they propose that "[t]he tax change could be implemented on a sliding scale, so that those with modest means could save tax free, while the wealthy continued to be taxed." 34

Their proposal is so close to current law as to be indistinguishable from it in its most important respects. The only difference is that, instead of protecting from current taxation only the middle-class savings for retirement, education, health care costs, or premature death, as our current system does, protection would also cover all savings accounts of the middle class, money which can be spent at any time for anything. ${ }^{35}$

It seems doubtful that such a change would encourage greater savings behavior, their stated goal (and the goal of many consumption tax supporters). The elasticity of savings behavior is a controversial topic among behavioral economists, but it is fair to say that most think that the overall savings rate is not very sensitive to tax incentives (or disincentives), that people choose to save or consume for reasons having little to do with the after-tax rate of return. ${ }^{36}$ The personal

${ }^{29}$ See id. at 50-52.

${ }^{30}$ Id. at $50-51$.

${ }^{31} I d$. at 52 (emphasis in original).

${ }^{32}$ Id. at 69 .

${ }^{33}$ Id. at 70 .

${ }^{34}$ Id.

${ }^{35}$ Id. at 69.

${ }^{36}$ See, e.g., Joel Slemrod \& Jon BakiJa, Taxing Ourselves: A Citizen's Guide to the Great Debate Over Tax Reform 180, 232-35 (2d ed. 2000) [hereinafter SLEMROD \& BAKIJA, 2d ed.]. 
savings rate has steadily decreased over the same time period during which increased tax subsidies for savings were enacted. Indeed, recent research shows that we have reached the crossover point: more tax revenue was forfeited under the savings subsidies in 2004 (\$112 billion) than was saved by individuals for any purpose $(\$ 100.8$ billion). ${ }^{37}$ However, this debate is beside the point for our purposes because the authors' larger concern, although not phrased in these terms, is that the present tax system should explicitly and more effectively take into account the decreasing amount of "discretionary" income earned by today's median earners, as measured empirically over time. Both their stories and their proposal have at heart an assumption that the tax system ought to explicitly take into account the "nondiscretionary" spending and saving required of the median household and adjust the tax burden, accordingly. I agree.

\section{THE ROYAL COMMISSION ON TAXATION}

In 1966, Canada's Royal Commission on Taxation recommended that the tax burden be "allocated in proportion to the discretionary economic power of tax units." "38 The Commission defined "discretionary economic power" as "the product of the tax unit's total economic power and the fraction of the total economic power available for the discretionary use of the unit." as "families and unattached individuals," of the total economic power available for discretionary use" as "the proportion of the unit's total economic power that does not have to be exercised to maintain the members of the unit." ${ }^{, 41}$ The Commission made immediately clear that "[m]aintenance is not synonomous [sic] with bare, physical subsistence. Rather, it denotes the provision of the services necessary to maintain the appropriate standard of living of the family or unattached individual relative to others." ${ }^{42}$ Finally, the concept of "total economic power" relates to a "comprehensive tax base," which the Commission said was broader than the income tax base then in place but which could, for convenience, be called an

37 See Edmund L. Andrews, Savings: Lots of Talk, But Few Dollars, N.Y. TIMES, Mar. 13, 2005, § 3, at 6 (describing research done by Elizabeth Bell, Adam Carasso, and $C$. Eugene Steuerle at the Urban Institute).

${ }^{38}$ ROYAL COMMISSION REPORT, supra note 3 , at 5.

${ }^{39}$ Id.

${ }^{40} I d$.

${ }^{41} I d$.

${ }^{42}$ Id. 
"income" tax base. ${ }^{43}$ The Commission then gave the following example:

Suppose that tax unit $\mathrm{A}$ has an income of $\$ 10,000$, and that one tenth of this income can be spent or not spent at the discretion of A. Suppose further that B has an income of $\$ 20,000$ and two tenths of this income is available for the discretionary use of B.... [T] he relative taxes imposed on A and $B$ should be as follows:

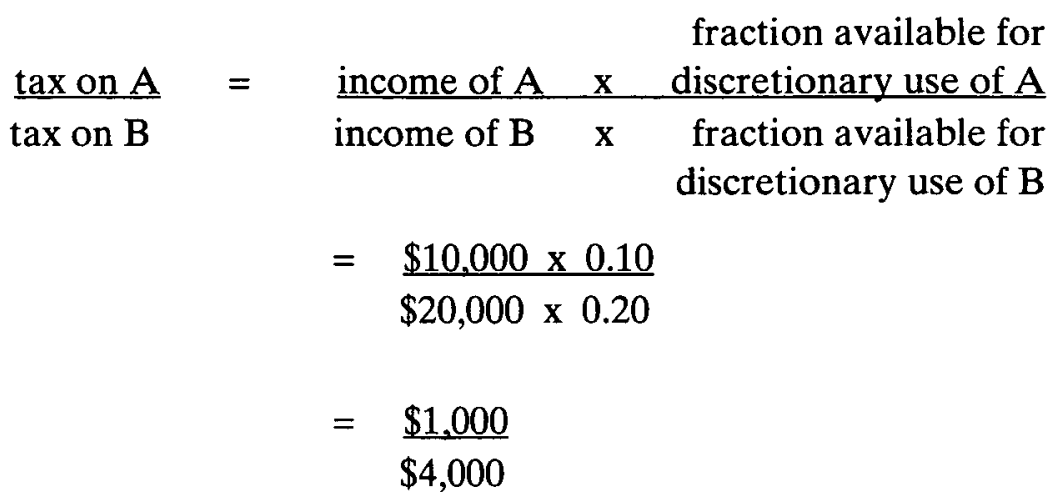

From this calculation it follows that the tax on B's income would be four times the tax on A's income. If a total revenue of $\$ 1,000$ is to be raised from $A$ and $B$, the rate of tax on the discretionary income of each unit should be 20 per cent (that is, 20 per cent of $\$ 1,000$ and $\$ 4,000)^{44}$

Crucial to the Commission's analysis is the reasonable assumption that:

[T] he greater the income of the unit the greater is the fraction available for discretionary use. As illustrated in the foregoing example, we believe a tax unit with an income of $\$ 10,000$ has a smaller proportion of that income available for discretionary use than an identical family with an income of $\$ 20,000$. $^{45}$

${ }^{43}$ Id. at 5-6; cf. Boris I. Bittker, A "Comprehensive Tax Base" as a Goal of Income Tax Reform, 80 HARV. L. REV. 925 (1967) (elaborating on the comprehensive income tax base).

44 ROYAL COMMISSION REPORT, supra note 3, at 6-7.

${ }^{45}$ Id. at 8 . 
One method that could be used to achieve the desired results would be "to establish an ascending schedule of proportions of income that would represent discretionary economic power, and then subject these to a proportional [i.e., flat-rate] tax." ${ }^{, 46}$ The Commission conceded that "the fraction of a tax unit's income available for discretionary use is not an objective phenomenon" ${ }^{\text {"47 }}$ but rather would result from the political process. It then gave an example of such an approach, using a hypothetical flat tax rate of $50 \%{ }^{48}$

\begin{tabular}{|c|c|c|c|c|c|c|c|}
\hline \multicolumn{2}{|c|}{} & \multicolumn{2}{|c|}{ Discretionary Income } & \multicolumn{2}{|c|}{$\begin{array}{c}\text { Tax on Discretionary } \\
\text { Income at an Assumed } \\
\text { Rate of 50\% }\end{array}$} & \multicolumn{2}{|c|}{} \\
\hline $\begin{array}{c}\text { Income } \\
\text { Bracket } \\
(\$)\end{array}$ & $\begin{array}{c}\text { Assumed } \\
\text { Fraction of } \\
\text { Income in } \\
\text { Bracket } \\
\text { Available for } \\
\text { Discretionary } \\
\text { Use }\end{array}$ & $\begin{array}{c}\text { From } \\
\text { Bottom } \\
\text { to Top } \\
\text { of } \\
\text { Bracket } \\
(\$)\end{array}$ & $\begin{array}{c}\text { Cumulative } \\
\text { Total to Top } \\
\text { of Bracket } \\
(\$)\end{array}$ & $\begin{array}{c}\text { From } \\
\text { Bottom } \\
\text { to Top of } \\
\text { Bracket } \\
(\$)\end{array}$ & $\begin{array}{c}\text { Cumulative } \\
\text { Total to Top } \\
\text { of Bracket } \\
\text { (\$) }\end{array}$ & $\begin{array}{c}\text { Marginal } \\
\text { Tax Rate } \\
\text { on } \\
\text { Income } \\
\text { in } \\
\text { Bracket } \\
(\text { a/ \%) }\end{array}$ & $\begin{array}{c}\text { Average } \\
\text { Tax Rate } \\
\text { on } \\
\text { Income at } \\
\text { Top of } \\
\text { Bracket } \\
\text { (b/\%) }\end{array}$ \\
\hline 0.195 & $(1)$ & $(2)$ & $(3)$ & $(4)$ & $(5)$ & $(6)$ & $(7)$ \\
\hline $195-390$ & 0.0 & 0 & 0 & 0 & 0 & 0 & 0.0 \\
\hline $390-781$ & 0.2 & 78 & 98 & 39 & 49 & 10 & 6.3 \\
\hline $\begin{array}{c}781- \\
1,562\end{array}$ & 0.3 & 234 & 332 & 117 & 166 & 15 & 10.6 \\
\hline $\begin{array}{c}1,562- \\
3,125\end{array}$ & 0.4 & 626 & 958 & 313 & 479 & 20 & 15.3 \\
\hline $\begin{array}{c}3,125- \\
6,250\end{array}$ & 0.5 & 1,526 & 2,520 & 781 & 1,260 & 25 & 20.2 \\
\hline $\begin{array}{c}6,250- \\
12,500\end{array}$ & 0.6 & 3,750 & 6,270 & 1,875 & 3,135 & 30 & 25.1 \\
\hline $\begin{array}{c}12,500- \\
25,000\end{array}$ & 0.7 & 8,750 & 15,020 & 4,375 & 7,510 & 35 & 30.0 \\
\hline $\begin{array}{c}25,000- \\
50,000\end{array}$ & 0.8 & 20,000 & 35,020 & 10,000 & 17,510 & 40 & 35.0 \\
\hline $\begin{array}{c}50,000- \\
100,000\end{array}$ & 0.9 & 45,000 & 80,020 & 22,500 & 40,010 & 45 & 40.0 \\
\hline $\begin{array}{c}100,000- \\
200,000\end{array}$ & 1.0 & 100,000 & 180,020 & 50,000 & 90,010 & 50 & 45.0 \\
\hline
\end{tabular}

The Commission then concluded that "a more familiar method to achieve the same result would be to apply to a base that measures the total economic power of each tax unit a schedule of progressive rates of tax." ${ }^{49}$ That is to say, the same tax can be computed by multiplying

46 Id. at 9.

${ }^{47}$ Id. at 7.

48 Id. at 11 . The reason why the income brackets in the chart reach only $\$ 100,000$ to $\$ 200,000$ is that the Commission assumed that all income in excess of $\$ 100,000$ was available for discretionary use. See id. at 8 . That is why the "discretionary income fraction" for that top bracket, which has a floor of $\$ 100,000$, is 1.0. That 1.0 fraction would continue to apply to all income above that listed in the chart.

Id. at 9. 
the marginal rates in the penultimate column above by the aggregate income (not limited to "discretionary" income) in each of the brackets in the first column.

But there is yet a third way, not discussed by the Commission, to achieve a workable result, which has the added benefit of taking into account real-life facts regarding nondiscretionary costs. Recall that the Commission rejected the assumption that nondiscretionary costs should be limited to those necessary for physical subsistence because such an approach "would imply that nondiscretionary expenses do not change with income," a constant rate of tax to a base consisting of total income less a fixed exemption." " Rather, the Commission believed that "most nondiscretionary expenses increase, although not proportionately, as income rises." ${ }^{, 52}$ That is to say, even though nondiscretionary costs increase as income rises, the Commission still believed that such costs did not rise as quickly as income so that "the greater the income of a tax unit the larger will be the fraction of that income available for discretionary use." $\$ 3$

While the Commission did not buttress this essential assumption underlying its analysis with empirical evidence, ${ }^{54}$ evidence does exist to support it, which makes building that assumption into a tax framework a defensible choice. For example, data from the Bureau of Labor Statistics show that "the share of average annual expenditures used to purchase food [including meals prepared at home, restaurant meals, fast food, carryout, and home delivery] declines from 14.9 percent to 11.6 percent as income increases from the third quintile to the fifth quintile." 55 Moreover, "[e]xpenditure shares for housing clearly decline across income quintiles.... While consumer units in the highest income quintile devote 22 percent of their total spending

$\begin{array}{ll}{ }^{50} & I d . \\ { }^{51} & I d . \\ { }^{52} & I d . \\ { }^{53} & I d . \text { at } 6 . \\ { }^{54} & \text { See, e.g., Michael J. McIntyre, What Should Be Redistributed in a }\end{array}$ Redistributive Income Tax?: Retrospective Comments on the Carter Commission Report, in THE QUEST FOR TAX REFORM: THE ROYAL COMMISSION ON TAXATION TWENTY YeARs LATER 189, 202-03 (W. Neil Brooks ed., 1988) (criticizing the "speculation about the percentage of a taxpayer's income available for discretionary expenditures").

${ }^{55}$ Abby Duly, Consumer Spending for Necessities, in U.S. DEP'T OF LABOR, Bureau of Labor Statistics, CONSUMER Expenditure Survey ANThology, 2003, REPORT 967 (Sept. 2003) 35, 36 [hereinafter ANTHOLOGY]. 
to shelter and utility costs, those in the lowest income quintile spend almost 30 percent." $" 56$ In other words, even though households clearly spend more in absolute terms on food and housing as income rises, these nondiscretionary outlays do not rise as fast as income rises, with the result that a larger proportion of additional income is comprised of discretionary income.

Thus, another way to accomplish the objectives of the Commission, consistent with these assumptions, would be to exempt from tax a fixed portion of income that is considered "nondiscretionary" (no matter what the income level of the household) but then to apply progressive rates to remaining income (to reflect the increasing portions of additional income that can reasonably be considered "discretionary"). The rate of progression would be a purely political decision, rather than an empirical one, but it would be imperative to retain a progressive rate structure (even if only mildly so) if the Nondiscretionary Deduction is to be a flat amount for all taxpayers.

Moreover, this fixed Nondiscretionary Deduction should be calibrated to take into account empirical evidence regarding the median costs for various items, not actual individual taxpayer expenditures (with the notable exceptions of charitable contributions and retirement savings), though the elements that sum up to each taxpayer's Nondiscretionary Deduction (such as whether or not the taxpayer has children, is a homeowner or renter, or, perhaps, is paying for college) should reflect the status of that taxpayer.

\section{THE CONTENTS OF THE NONDISCRETIONARY DEDUCTION}

In a 2002 article $^{57}$ Lawrence Zelenak proposed a universal Earned Income Allowance for all workers. His proposal can possibly be seen as a reexamination of the proper scope of "business" expenses, an argument that, in deciding where the difficult line should be drawn between deductible "business" expenses and nondeductible "personal" expenses under an income tax, a portion of what is usually characterized as "personal consumption" should in fact be deductible as a cost of doing business (being employed). In that sense, his proposal is not inconsistent with an "income" tax because business expenses are unobjectionably deducted under an "income" tax in order to avoid the double taxation of the same dollars to the same

\footnotetext{
${ }^{56}$ Id. at 36 .

57 Zelenak, supra note 23.
} 
taxpayer. ${ }^{58}$ On the other hand, he could be seen as arguing that, even if the costs of being an employed person are "personal," they ought to be deductible because not fairly available for contribution to the fisc, i.e., because (in my nomenclature) they are "nondiscretionary."

In so doing, Professor Zelenak turns to the Consumer Expenditure Survey ${ }^{59}$ periodically published by the Department of Labor to document the costs of commuting, work clothes, and the extra costs of meals at work. ${ }^{60}$ He suggests, in the end, a formuladriven deduction that takes into account the median worker's costs, rather than actual costs. Whether his use of a formula is based in theory or is simply the second-best alternative necessitated by administrative ease is a bit unclear (at least to me) from his article. With respect to commuting costs, for example, he says:

Of course, some taxpayers incur unnecessarily high commuting expenses for personal reasons, which suggests that a deduction for actual commuting expenses would be theoretically inappropriate-as well as being the source of major compliance and enforcement difficulties. A better approach would be a formula-based allowance, which would permit a working taxpayer to deduct typical commuting expenses without having to substantiate actual expenses (and thus without regard to whether the taxpayer's actual expenses were higher or lower than the deduction produced by the formula). This approach might be described as assuming there is no personal element in choosing to have, say, a 10mile commute, but that any longer commute is due to personal considerations. This can achieve only very rough justice. It is overly generous for the taxpayer who walks to work, and inadequate for the taxpayer with an unavoidably

${ }^{58}$ If every dollar of "gross" business income is included in the tax base and we disallowed deductions of expenses incurred in producing that income, we would be double taxing that income to the extent of the denied deductions.

${ }^{59}$ More accurately, he cites a book that, in turn, draws on data in the Consumer Expenditure Survey. Zelenak, supra note 23, at 59-62, citing DAN M. MCGILL, KYLE N. Brown, John J. Haley \& Sylvester J. Schieber, Fundamentals of Private PENSIONS 391-98 (7th ed. 1996).

${ }^{60}$ Zelenak, supra note 23 , at 45 . He also considers whether the allowance should include the costs of replacing imputed income, such as child care, house cleaning, yard care, convenience foods, and laundry services, as well as whether the employee's share of payroll taxes ought to enter into the equation. For reasons that Zelenak develops in his article, he chooses to focus solely on commuting, work clothes, and meals at work. See id. at 45-47. 
lengthy commute. ${ }^{61}$

His statement that a deduction for actual expenses incurred would be "theoretically inappropriate" but that a formula allowance can achieve "only very rough justice" seems to be internally inconsistent. What he may be saying, however, is that it would be ideal if actual costs (rather than a formula) were used for those whose outlays were below the median (denying the deduction to the walker, for example), at or near the median, and above the median to the extent that it could be shown that the cost was unavoidable. It is only because the record-keeping attending use of actual cost would be burdensome (for those below the median) and the determination whether costs were "necessary" (for those above the median) would be administratively difficult that he accedes to use of a formula in place of the ideal use of actual costs. His preference in theory for use of actual costs in most instances (except those for excessive costs) is apparent in his later assertion that "considerations of administrative feasibility dictate ... a formula deduction, rather than a deduction based on each worker's actual expenses." ${ }^{62}$ And: "A formula deduction for work-related expenses is premised on the notion that it is better to do rough justice with an easy-to-administer formula than to attempt exact justice by measuring the actual expenses of each taxpayer." ${ }^{63}$

Zelenak's use of data from the Consumer Expenditure Survey suggests a fruitful avenue for exploring the Nondiscretionary Deduction that I propose should replace the Standard Deduction, the Personal and Dependent Exemption Deductions, the Child Tax Credit, the Deductions for State and Local Income and Property taxes, as well as some other deductions and credits currently allowable. If this system is adopted, however, the government will have to do some further empirical work. Like Professor Zelenak, I suggest use of a formula allowance that should be modified every several years based on data collected that documents the median cost of various nondiscretionary outlays for various-sized households. This would mean that those who spend less than the median in the aggregate for the various items composing the Nondiscretionary Deduction would, in effect, enjoy tax-free savings outside the taxpreferred vehicles specified under current law, consistent with the implicit suggestion made by Elizabeth Warren and Amelia Warren Tyagi described in Part III, above.

\footnotetext{
${ }^{61}$ Id. at $46-47$ (emphasis in original).

${ }^{62}$ Id. at 59 .

${ }^{63}$ Id. at $61 \mathrm{n} .102$ (emphasis in original).
} 
For example, assume that median household income is $\$ 43,000^{64}$ and that the Nondiscretionary Deduction for this household is, say, $\$ 20,000$ (because that is the sum of the median costs of the various items constituting the Nondiscretionary Deduction for this household, described below). What about those who spend less? Professor Zelenak would prefer, on principle, to deny the worker who walks to his job an allowance for the costs of commuting. His formula allowance would, in fact, grant the walker a commuting allowance but only because of the administrative difficulty involved in policing those who spend below the median. But in a tax system that is concerned with addressing the problems identified by Warren and Tyagi, allowing the "too generous" Nondiscretionary Deduction to the lowspending median family accomplishes their stated goal: protecting from taxation - and thus encouraging - low and middle-class savings outside the preferred savings vehicles, available for lifetime use without limit when the unexpected job loss, etc., occurs. A similar value informs the treatment of households that earn below the median income, who would nevertheless be allowed the full Nondiscretionary Deduction based on the costs expended by the median income household.

\section{A. Shelter}

The costs of shelter are an essential ingredient in the Nondiscretionary Deduction. Current law provides a panoply of tax reductions for the homeowner, including most notably the triumvirate of the deduction for "qualified residence interest" on both acquisition indebtedness and home equity indebtedness, ${ }^{65}$ the deduction for state and local real estate property taxes, even though unconnected with a trade or business, ${ }^{66}$ and the exclusion of most home sale gain. ${ }^{67}$ The tax expenditure totals for the housing subsidies are among the highest in the Code. The estimates for 2005 (in billions) are: $\$ 72.6$ for the home mortgage deduction, $\$ 22.9$ for the exclusion of capital gains on sales of principal residences, and $\$ 19.6$ for the property tax deduction

${ }^{64}$ To be precise, the median household income for both 2002 and 2003 was $\$ 43,318$, according to the Census Bureau. See Carmen DeNavas-Walt, Bernadette D. Proctor \& Robert J. Mills, Income, Poverty, and Health Insurance Coverage in the United States: 2003 at 2 (U.S. Census Bureau Current Population Reports, Report No. P60-226, Aug. 2004), available at http://www.census.gov/prod/2004pubs/p60-226.pdf.

${ }^{65}$ See I.R.C. $\$ 163(\mathrm{~h})(3)$.

${ }^{66}$ See I.R.C. \& 164(a)(1).

${ }^{67}$ See I.R.C. $\$ 121$. 
for homeowners. ${ }^{68}$ The home mortgage deduction alone is estimated to cause individual tax rates to be about $7.5 \%$ higher than they otherwise would be. ${ }^{69}$ There is no explicit tax reduction for the costs of shelter for the renter, though presumably the Standard Deduction (taken by virtually all renters) includes some component for shelter costs. Notice that the Standard Deduction for the renter is a fixed amount, no matter where the taxpayer lives; a renter in New York City is entitled to the same Standard Deduction as a renter in rural Montana, where rents are much lower than in New York City. In this way, the tax system takes into account the varying costs of shelter due to geography to a much greater degree for the homeowner than for the renter.

The current income tax treatment of shelter costs are recognized by virtually all economists to be dysfunctional. Eugene Steuerle, for example, observes that "theorists of all types ... especially do not like the ways that the current income tax system favors owner-occupied housing over other forms of capital investment." a number of economic models, this is one of the larger sources of inefficiency arising from the income tax." blunt when he says that "nowhere is the surrender of economic principles to political expediency more complete than in the U.S. tax policy for housing." 72

The distortions are well-known. As Sullivan pithily summarized them, while focusing in particular on the deduction for home mortgage interest:

The economic case against the mortgage interest deduction is clear-cut. It is a huge subsidy that causes massive efficiencydraining distortions in the economy. Capital and saving

68 See Martin A. Sullivan, The Economics of the American Dream, 106 TAX NOTES 407,409 (2005). In terms of 5-year totals, the deduction for home-mortgage interest is expected to be the third-highest tax expenditure from 2005 to 2009 , coming in at $\$ 434$ billion. Only the net exclusion for contributions to and earnings on employer-provided pension plans ( $\$ 567$ billion) and the exclusions for employerprovided health care and long-term care premiums ( $\$ 493$ billion) come in higher. See Dustin Stamper, Last Year's Tax Bills Increase Tax Expenditures - Again, 106 TAX NOTES 271, 271 (2005).

69 Joel Slemrod \& Jon BaKiJa, TAXing OURSElves: A Citizen's Guide to THE DEBATE OVER TAXES 219 (3d ed. 2004) (emphasis in original) [hereinafter SLEMROD \& BAKIJA, 3d ed.].

${ }^{70}$ STEUERLE, supra note 2, at 241.

71 Id. at 257 n.5.

${ }^{72}$ Sullivan, supra note 68 , at 407. 
channeled by the tax code into housing is largely drawn from the business sector. The mortgage interest deduction means the economy has less business capital, lower productivity, lower real wages, and a lower standard of living .... Most economists understand - but hate to waste their breath explaining - that probably the most sure-fire way to improve the competitiveness of the American economy is to repeal the mortgage interest deduction.

What does the economy get in return for its sacrifice? For the most part, just bigger houses. ${ }^{73}$

The reason why it makes economic sense for a taxpayer to place more of his investment dollars in owner-occupied housing (by purchasing a larger house than he otherwise would) than in other investment vehicles is that the average tax rate on owner-occupied housing is a negative $5.1 \%$ (due to the tax subsidies described here), while the average tax rate on all capital returns is $13.8 \% .^{74}$ The resulting misallocation of capital exacts efficiency costs. If the efficiency costs are thought to be necessary in pursuing the quest of increasing the homeownership rate, we are sorely disappointed here, as well. Homeownership rates in similar economies, such as Canada and Australia, are virtually identical to that in America, even though no home mortgage interest deduction is allowed in these other countries. Moreover, the value of the subsidies has changed dramatically over the past several decades as tax rates and interest rates have fluctuated, but the homeownership rate has remained remarkably constant at 65 to $70 \%$. $^{75}$

The home mortgage deduction is also suspect on fairness grounds. The upside-down nature of these subsidies is well-known. "Nearly $80 \%$ of the benefits from the mortgage-interest and property-tax deductions go to the top $20 \%$ of taxpayers in terms of income.... Only $5 \%$ of the benefits go to people in the bottom $60 \%$ of the

${ }^{73} I d$.

74 See Congressional Budget Office, Taxing Capital Income: EFFective RATES AND APPROACHES TO REFORM 8, tbl. 1 (Oct. 2005). The average tax rate on all capital returns "is strongly influenced by a negative rate" on owner-occupied housing. In other words, the overall $13.8 \%$ average tax rate on capital would be higher absent the preferred taxation of owner-occupied housing.

${ }^{75}$ See Edward L. Glaeser \& Jesse M. Shapiro, The Benefits of the Home Mortgage Interest Deduction, in 17 TAX PoL'Y \& THE ECONOMY 37, 40 (James M. Poterba ed., 2003). 
income scale - those who may be struggling to afford a home. ${ }^{.76}$ As phrased by Edward L. Glaeser and Jesse M. Shapiro, who recently published an exhaustive empirical study on the benefits of the home mortgage deduction, "the home mortgage interest deduction is a particularly poor instrument for encouraging home ownership because it is targeted at the wealthy, who are almost always homeowners." They find that the "deduction serves mainly to increase housing consumption [by encouraging people to buy larger houses than they otherwise would absent the deduction] and to change the progressiveness of the tax code.,"78

They note that the "case for subsidizing housing consumption is based on a desire either to redistribute income to people who buy a lot of housing or to encourage people to consume more housing." Since they "have little to say about the benefit of redistributing to those who consume a lot of housing," positive and negative externalities of encouraging people to consume more housing by buying larger houses than they otherwise would. While they found some evidence that owning a home and owning a larger home encourages "aesthetic externalities" (e.g., home maintenance and gardening), ${ }^{81}$ they found far greater evidence of negative externalities. For example, the encouragement to buy everlarger homes hurts inner cities with older, smaller housing. And because it disproportionately encourages spending on housing among the wealthy rather than the poor, it increases segregation by income. ${ }^{82}$

Another possible side effect of the tax subsidies for owneroccupied housing is that they artificially inflate the value of housing, as the subsidies get built into the cost. The real estate industry has vociferously argued against repeal of these subsidies on the ground that housing prices would fall. Although that might be considered a good thing for the renter looking to become a first-time homebuyer, it would severely disgruntle current homeowners, who tend to vote. For this reason, even some proponents of a flat tax on wages with no deductions have relented and conceded that the home mortgage

${ }^{76}$ James R. Hagerty, Housing Sector Seeks No Tax Remodeling, WALL ST. J., Jan. 31, 2005, at A2.

\footnotetext{
77 Glaeser \& Shapiro, supra note 75 , at 40.

${ }^{78}$ Id. at 40 .

${ }^{79}$ Id. at 50 .

${ }^{80}$ Id.

${ }^{81}$ Id. at 52-56, 64-65.

${ }^{82}$ Id. at 58-59.
} 
interest deduction (if not the property tax deduction) should remain. ${ }^{83}$ President Bush instructed his Advisory Panel on Federal Tax Reform, created in January 2005 to submit a report containing revenue neutral policy options for reforming the Code, to "recogniz[e] the importance of homeownership ... in American society."

It is not absolutely clear that home prices would collapse with repeal of the subsidies. "Britain managed to phase out a similar break for mortgage interest over 12 years, ending in 2000 . There was no crash in house prices, which kept rising, and no taxpayer revolt." Even so, because I do not propose outright repeal of shelter deductions, but rather reform, a collapse in home prices is not likely. I would predict that reductions in value, if any, would be concentrated at the very high end (where taxpayers today enjoy outsize benefits).

For renters, the portion of the Nondiscretionary Deduction pertaining to shelter should equal a specified percentage of the sum of the national median annual rent and the national median annual cost of utilities paid by renters. For homeowners, the portion of the Nondiscretionary Deduction pertaining to shelter should equal a specified percentage of the sum of the national median annual cost of utilities paid by homeowners, the annual rental value of the national median-priced home, and the national median annual real estate property tax for owner-occupied housing. By "specified percentage," I mean a selected percentage based on revenue needs, such as, for example, $40 \%$ or $50 \%$. Whichever percentage amount is selected should be the same for each of the items comprising the Nondiscretionary Deduction.

For example, the 2000-2001 Consumer Expenditure Survey (published in 2003) shows that average annual rent paid by middle quintile renters was $\$ 2,588 .{ }^{86}$ The average annual rent paid by middle quintile renters would not be the same as the national median rent paid by all renters. This is because the survey uses the average (for each quintile) for the total population in that quintile, even if the item under review was not purchased by all households. In other words, not everyone in the middle quintile rented their premises; no doubt a good number were homeowners. Therefore, the average stated rent for all households in that quintile necessarily understates the rent paid

83 See Sullivan, supra note 68, at 408-09.

${ }^{84}$ Exec. Order No. 13,369, 70 Fed. Reg. 2323 (Jan. 7, 2005).

${ }^{85}$ Hagerty, supra note 76.

${ }^{86}$ See Bureau of Labor Statistics, U.S. DeP'T OF LABOR, RePORT No. 969, CONSUMER EXPENDITURE SURVEY, 2000-2001, at 11 tbl. 1 (2003) [hereinafter CES]. 
by an average renter in that quintile. ${ }^{87}$

Moreover, the median rent itself may actually be paid by someone who is not in the median income quintile. Additional empirical work would, therefore, need to be done; I invoke this data merely to illustrate the nature of the proposal. For purposes of illustration, assume that further research shows that the national median annual rent for those who rent is $\$ 7,000$. Nationwide surveys of utility costs are not segregated by "renter" and "homeowner," but average cost to those in the median quintile for utilities (natural gas, electricity, fuel oil, telephone, and water) was $\$ 2,663{ }^{88}$ If further study indicates that the median utility cost to renters was $\$ 1,000$, then the shelter portion of a renter's Nondiscretionary Deduction would be a specified percentage (say, $40 \%$ ) of $\$ 8,000$ ( $\$ 7,000$ plus $\$ 1,000$ ), or $\$ 3,200$.

For homeowners, the shelter deduction would not differentiate between those who use debt to purchase a house and those who don't (or who have paid off their debt). The 2000-2001 Consumer Expenditure Survey shows that the average property tax paid by those in the middle quintile (which, again, likely understates the median property tax paid by homeowners) was $\$ 1,948 .{ }^{89}$ Assume that further research shows the actual median to be $\$ 3,000$. As of April, 2006, Internal Revenue Service (Service) data show that the average nationwide purchase price was $\$ 258,700$ for new and existing singlefamily residences. ${ }^{90}$ The annual rental value of this median-price house would need to be determined and added to the median property tax. Assume that the annual rental value of this median house is $\$ 16,800$ (or $\$ 1,400$ per month). Finally, the median utility costs paid by homeowners would need to be added for a final total. Assume they total $\$ 3,200$. The shelter portion of a homeowner's Nondiscretionary Deduction would equal a specified percentage (say, $40 \%$ ) of this $\$ 23,000$ total $(\$ 3,000$ plus $\$ 16,800$ plus $\$ 3,200)$, or $\$ 9,200$. There would be no shelter deduction for a second home, as a second home could reasonably be considered "discretionary."

These figures would be determined by the government based on data collected by it every few years so that the amount sheltered from taxation reflects actual changes in the cost of nondiscretionary outlays. $^{91}$ Taxpayers would simply consult a table in the instruction

\footnotetext{
${ }^{87}$ Id. at 9.

${ }^{88}$ Id. at 11 tbl. 1.

${ }^{89}$ Id.

90 See Rev. Proc. 2006-17, 2006 IRB LEXIS 132 (Apr. 3, 2006).

91 The speed with which the government researched information regarding the
} 
booklet for the amount appropriate for their filing status and their status as a renter or a homeowner. Homeowners would still have an advantage over renters, as their shelter deduction would no doubt be significantly higher than the renter's shelter deduction (more than two-and-a-half times higher, in the hypothetical example), thus satisfying the President's mandate that the tax law recognize the importance of homeownership in American society. Nevertheless, it does away with the unfair upside-down nature of the current homeowner subsidies and removes the economically inefficient incentive to buy ever-larger homes. The approach also explicitly recognizes that renters must spend nondiscretionary dollars on shelter. Finally, using medians rather than averages prevents the outsize purchases of the very wealthy to inflate the deductions severely. ${ }^{92}$

average state sales tax paid by taxpayers in each of the fifty states after enactment of The American Jobs Creation Act of 2004 shows how easily the government should be able to collect the relevant information. See I.R.S. PUBLICATION 600 (2004), available at http://www.irs.gov/pub/irs-prior/p600-2004.pdf. The booklet shows the average sales tax paid by those earning income of $\$ 0$ to $\$ 20,000, \$ 20,000$ to $\$ 30,000, \$ 30,000$ to $\$ 40,000$, etc., up to $\$ 200,000$ (and then over $\$ 200,000$ as a group) for each of the 50 states and for taxpayers with one, two, three, four, or five exemptions. The Act was passed in October, and the publication reached people's homes in January.

${ }_{22}$ President Bush's Tax Reform panel recommended phasing out the deduction for home mortgage interest and replacing it with a $15 \%$ tax credit. A taxpayer paying $\$ 100$ in mortgage interest would credit $\$ 15$ of that interest against his tax due, the economic equivalent of deducting that $\$ 100$ by someone in the $15 \%$ tax bracket. In other words, a taxpayer in the $30 \%$ bracket would enjoy the same $\$ 15$ in tax savings as someone in the $15 \%$ tax bracket, thus eliminating the upside-down nature of the subsidy under current law. In addition, the interest paid on debt exceeding $\$ 227,000$ to $\$ 412,000$ (depending on geographic location) would not be creditable, thus better targeting the buyer who is on the homeownership margin and eliminating the inefficient economic incentive to buy ever-larger homes in lieu of more productive investments for the economy. See http://www.taxreformpanel.gov (for a copy of the report).

My shelter proposal uses a deduction rather than a credit (and goes well beyond interest costs) because the proposed Nondiscretionary Deduction defines and refines the tax base premised on "discretionary income." Tax-base-defining expenditures are typically cast in the form of deductions, while credits are typically used in the case of pure tax expenditures, i.e., forms of government spending through the tax law to provide a subsidy to certain groups or to provide an incentive to change behavior. If the ideal tax base is considered to be either "income" or "consumption" in traditional terms, then a tax reduction for housing is a pure tax expenditure. Viewed through that lens, the Panel's recommendation makes good sense. (Moreover, again viewed through that lens, an even more efficient proposal to increase the homeownership rate would be to craft a subsidy targeted solely at first-time home buyers.)

In short, the difference between the approach to shelter costs described in this 
To be entitled to the shelter deduction, homeowners (if challenged) would need to document their homeownership, and renters would need to document that they incurred rent. ${ }^{93}$ Married homeowners filing jointly would take $100 \%$ of the deduction, while unmarried co-owners filing tax returns as single individuals would each take $50 \%$. Roommates sharing a rental residence would similarly split the deduction pro rata. If a renter buys a home, the taxpayer should, as a simplification matter, be entitled to the larger "homeowner's" deduction for the entire year, just as new parents are entitled to a full-year's Dependent Exemption Deduction under current law for an infant born on December 31.

Note that the proposal described above uses national medians for the shelter component of the Nondiscretionary Deduction, rather than state-by-state data (or even regional information within a state, differentiating between, for example, New York City and upstate rural New York). This approach applies to other costs discussed below as well, such as for food and transportation. In fact, this approach explicitly rejects taking into account the differential costs of living around the country. The proposal takes as its starting point the Standard Deduction and Personal and Dependent Exemption Deductions, which similarly are a uniform, national figure, regardless of where a taxpayer lives. To the best of my knowledge, it has never been proposed before that these amounts ought to vary by geographic location. On the other hand, an argument that the Nondiscretionary Deduction ought to take into account the geographic differences in the cost of living is not a trivial one. After all, the annual property tax due on a $\$ 189,000$ home (the national median price in January of $2005)$ was $\$ 6,020$ in Houston, $\$ 1,831$ in Mount Vernon, Indiana, and $\$ 876$ in Davenport, Florida. ${ }^{94}$ Therefore, I shall first discuss why a single, uniform amount for shelter costs might be defensible before offering an alternative that might prove more politically palatable.

article and the Panel's approach is a deeply theoretical one. My approach attempts to refine the ideal tax base based on the notion of "discretionary income." The panel's approach views the home mortgage interest tax subsidy as a non-tax provision that is merely implemented through the Internal Revenue Code.

${ }_{93}$ To prevent abuse, nominal "rent" paid to parents by teenagers with part-time jobs living at home would not generate a shelter deduction for the teenager. If overtaxation of teenagers is considered a problem upon replacement of the Standard Deduction with the multifaceted Nondiscretionary Deduction, Congress could enact an exclusion of, say, the first $\$ 1,000$ of earned income from tax for those not entitled to take the Nondiscretionary Deduction.

${ }_{94}$ See Josée Rose, Money's Worth, WALL ST. J., Mar. 9, 2005, at D3. 
At least with respect to higher income taxpayers, it might be consistent with the fairness constraints assumed in this article (i.e., that a tax base consisting of "discretionary income" is fair) to conclude that choosing where to live is a discretionary choice. A doctor may choose to practice at Mt. Sinai in New York instead of at the Cleveland Clinic in Cleveland (or vice versa) because of the quality of life available in each location and the amenities that each happens to personally value. The one who chooses to live in Cleveland may prefer the relatively low cost of living, the Cleveland Orchestra, and the convenience of upscale, close-in suburbs, while the doctor who practices in New York may prefer the cultural diversity and excitement of New York, the New York City Ballet, and the ability to live in a high-rise building in the heart of it all. If the doctor ends up choosing New York, with its higher shelter costs, the doctor has chosen, in a nontrivial sense, to spend more of his or her income on shelter. The excess of what is actually spent in New York over what could have been spent in Cleveland (assuming, for this purpose, that Cleveland shelter costs represent the median) can fairly, in my view, be considered "discretionary" income and thus fairly within the tax base.

Using national median costs (and thus ignoring the actual higher living costs in some locations over others) is contrary to a proposal advanced by Michael Knoll and Thomas Griffith in a recent article, where they argued that a "failure to adjust individuals' tax liabilities for different regional living costs misallocates capital and labor throughout the economy, discouraging investment and employment in high-cost regions and encouraging it in low-cost regions." this tax-induced disincentive for employers to hire in high-cost regions inefficient, and they propose a system "designed to ensure that employees with the same real after-tax income pay the same amount in tax regardless of where they locate. This can be achieved by dividing each employee's income by the ratio of her salary to the equivalent salary in a region with the national average cost of living." The effect of the equation is to exempt from tax "the additional salary that compensates for the higher cost of living in high-cost regions and [to tax] the increased purchasing power that compensates for the lower nominal salary earned in low-cost regions. $" 97$

${ }^{95}$ Michael S. Knoll \& Thomas D. Griffith, Taxing Sunny Days: Adjusting Taxes for Regional Living Costs and Amenities, 116 HARV. L. REv. 987, 989 (2003).

${ }^{96}$ Id. at $1001-02$.

${ }^{97}$ Id. at 1002 . They propose an alternative means of arriving at the same result using the relative cost of living as the adjustment multiplier. 
If I understand their proposal correctly, this would have the effect of reducing the nominal tax paid by the investment banker in New York City (where living costs are high) and increasing the nominal tax paid by the migrant farm worker in dusty, rural New Mexico (where living costs are low). They claim that they are focusing solely on efficiency concerns (and not fairness concerns), and their models seem to assume that rational employers are avoiding the high-cost locales and flocking to low-cost locales across the country because of these tax incentives and disincentives under current law.

Viewed from the perspective of current law, however, their proposal was not convincing to me - simply because I know of no empirical evidence supporting these underlying assumptions. It seems to me that the most notable high-cost areas (such as many areas in California and New York City) are not seeing a significant exodus of employers, and the low-cost Midwestern states (such as the Dakotas, Wyoming, Ohio, Indiana, etc.) are not seeing a huge influx of residents, notwithstanding the relatively low cost of living. In fact, anecdotal evidence supports just the opposite migration, continuing the decades-old exodus from lower-cost rural areas to higher-cost urban areas. Indeed, small towns such as Crosby, North Dakota, Ellsworth, Kansas, and Plainville, Kansas, are currently giving away plots of land and country club memberships to those who move there as an incentive to attract in-migration. ${ }^{98}$

My proposal could be said to discriminate more dramatically in the way feared by Professors Knoll and Griffith. They would complain of its economic inefficiency. Whether their fears of an inefficient exodus from high-cost areas to low-cost areas would actually transpire simply because of the federal income tax laws is difficult to predict, as there are so many other factors, including location of extended family and personal desires, that enter into the decision of where to live. Indeed, if someone would choose to live in the high-cost area even though no tax reduction accompanies the decision, allowing such a reduction would seem to create inefficient windfall benefits. The key question is why people choose to live where they do, which is similar to asking why people buy houses instead of rent. Is it truly the tax benefits that are causing them to make the decision to buy rather than rent? Would many actually prefer renting but are buying solely because of the tax treatment of home ownership? With respect to the Midwest land giveaways noted

${ }^{98}$ See Bob Greene, Empty House on the Prairie, N.Y. TIMEs, Mar. 2, 2005, at A19. 
above, one commentator has observed:

[I]f the giveaway programs fail to bring about a new land rush, maybe it will be no one's fault. The United States is no longer quite so young a country; we've been here a while, and nations, like people, get set in their ways. If the great urbanrural population divide stays the way it is, it may be because we all have chosen to live this way, and are not about to change. ${ }^{99}$

If, however, this concern is considered sufficiently serious to warrant a response in the tax law even for high-income taxpayers, who presumably have more mobility than low- and middle-income taxpayers, the median costs could be considered state-by-state, similar to the state-by-state sales tax data issued by the Service under section 164(b)(5)(H). ${ }^{100}$

The case in which the argument is persuasive to me that the higher living costs incurred in some geographic locations cannot fairly be considered incurred by choice is that of low- and middle-income workers - for example, the janitor in New York City. But the appropriate response may not necessarily be to adjust the national "median" that is taken into account in the Nondiscretionary Deduction (which would apply to the benefit of high- and low-wage workers alike). Rather the appropriate response would be to increase the "specified percentage" of the national median that is deductible by those who live in a "high-cost" area but who earn less than a specified amount, since those are the taxpayers for whom the choice of geographic location may not be "discretionary." For example, if the generally applicable "specified percentage" that can be deducted of the national median is $40 \%$ for most taxpayers, perhaps that percentage can be increased to $50 \%$ for those who live in specified "high-cost" areas and who earn less than, say, $\$ 100,000$ or earn less than twice the median wage for the high-cost state (or the metropolitan area). The number-crunching would, once again, simply be reflected in applicable tables prepared by the government.

A final refinement to the shelter portion of the Nondiscretionary Deduction should be to calculate the components described above (median property taxes, rental value of median-priced home, and median utilities for homeowners, and median rent and utilities for renters) for households containing various numbers of children and

${ }^{99}$ Id.

${ }^{100}$ See supra note 91. 
other dependents. That is to say, instead of adjusting for the additional costs of children through a separate Dependent Exemption Deduction and Child Tax Credit, the components of the Nondiscretionary Deduction itself could be adjusted directly to account for family size. The goal would be, once again, to capture more accurately the median cost changes in the various components that comprise the Nondiscretionary Deduction that arise with each new child. The median home price for a married couple with four children, for example, is surely significantly higher than the median home price for a single individual. ${ }^{101}$ For example, the 2000-2001 Consumer Expenditure Survey shows that average total annual housing cost for all households containing one person was $\$ 8,371$, for households containing two persons was $\$ 12,944$, and so on to $\$ 17,317$ for households with five or more persons. ${ }^{102}$

The current analogy would be to the sales tax tables under section 164(b)(5)(H) published by the Service. The government gathered empirical information regarding the sales tax experience of taxpayers in each of the fifty states by household size. ${ }^{103}$ For each state, there are six columns, with the first showing the sales tax deduction for households with one exemption, the second column showing the sales tax deduction for households with two exemptions, and so on until the sixth column, which shows the sales tax deduction for households with more than five exemptions. While I do not recommend as my first choice state-by-state determinations, I do recommend the determination of median outlays for households of varying sizes with respect to each component of the Nondiscretionary Deduction.

Finally, what about the gain from the sale of a primary residence, currently excludable to the extent of $\$ 500,000$ for a married couple and $\$ 250,000$ for single individuals? ${ }^{104}$ Gain from the sale of a home, like gain from the sale of any other asset, should be taxed to the extent it is considered "discretionary" income, which generally means that it should be taxed to the extent that it (and other income) exceeds

101 Although the decision whether or not to have children can, on some level, be considered "discretionary," with the higher living costs associated with children thus viewed as "discretionary," I assume that the current political and social pressures to recognize the increased costs associated with children as "nondiscretionary" will continue and thus incorporate this view into my proposal.

${ }^{102}$ See CES, supra note 86 , at 23 tbl. 4. These numbers do not reflect the medians that $I$ suggest be used for each category, but they are emblematic of the phenomenon.

${ }^{103}$ See I.R.S. PUBLICATION 600 (2004), supra note 91.

${ }^{104}$ See I.R.C. $\$ 121$. 
the amount of the taxpayer's Nondiscretionary Deduction (and other available deductions) for the year. Artificially channeling excessive investment dollars into homes instead of stock or business assets because the gain on the sale of this asset will be tax-free (while the gain on business and investment assets will be taxed) results in an inefficient allocation of investment dollars, as described earlier. Nevertheless, even if reducing gain on asset sales by the amount representing inflation gain may be unwise for assets generally (discussed below in Part V), the gain on sales of homes could easily be reduced by the amount that represents merely inflation gain between the year of purchase and the year of sale so that only the portion representing a real wealth accession is taxed. ${ }^{105}$

The simple tax reporting form that would be completed for the sale of a primary residence would first instruct the taxpayer to calculate realized gain using adjusted basis and amount realized, as under current law. The form could then easily include a table listing every year for the last, say, 100 years with its corresponding cumulative inflation adjustor percentage. The taxpayer would be instructed to multiply the realized gain on sale by the cumulative inflation adjustor percentage listed beside the year the home was purchased, which would be close to $100 \%$ for homes purchased in the year before sale and would progressively diminish the longer the home was held (as more of the gain represents inflation). The government would determine these percentages, and a decision would have to be made whether to use the increase in prices generally each year (such as increases in the consumer price index) or to use the increase in median home prices each year. Whichever choice is made, greater accuracy regarding the amount of the taxpayer's true wealth accession can be had in this context with little administrative difficulty. Conversely, a blanket exclusion of all gain for most taxpayers is inconsistent with the conceptual rationale developed in this article.

${ }^{105}$ Some of the objections pertaining to inflation indexing for asset basis in general, including the unacceptable arbitrage that would easily occur if we indexed asset basis but did not index debt basis, see infra note 199 and accompanying text, would not be a problem in this particular context, as there would be no more home mortgage interest deduction per se. Moreover, sales of homes (unlike assets generally) are relatively infrequent, and simplifying conventions could be used in determining the cumulative inflation adjustor percentage that would be multiplied by the sale gain, such as assuming that the home was purchased and sold precisely in the middle of the year (rather than on the date actually sold and purchased). For all of these reasons, there should be no conceptual or administrative objection to eliminating taxation of inflation gain in this limited context. 


\section{B. Food}

The 2000-2001 Consumer Expenditure Survey shows that the average annual cost for food for households in the median quintile was $\$ 5,042$. This includes households of all sizes and includes both food eaten at home $(\$ 3,113)$ and food eaten away from home $(\$ 1,929)$. It does not include the cost of alcoholic beverages, which averaged $\$ 331$ for households in the median quintile. ${ }^{106}$

Since everyone must eat, the downward bias described earlier for rent is likely less pronounced. Moreover, the average expenditure for those in the median quintile is also likely close to the actual median expenditure for food nationally. But the amounts listed above are for each "consumer unit," essentially each household. ${ }^{107}$ No differentiation is made between single-individual households and, for example, households containing a married couple with five children. Data adjusted for household size is presented for all households, in the aggregate, but not for median households of each size. For example, the average annual food costs (both eaten at home and away) for one-person households in the survey year was $\$ 2,835$, for two-person households was $\$ 5,291$, and for households with five or more persons was $\$ 8,194$. $^{108}$

Just as suggested with respect to the shelter component of the Nondiscretionary Deduction, the median amount spent on food should be determined for various household sizes. Since eating food prepared outside the home might reasonably be considered "discretionary," these median amounts could reasonably be limited to food eaten at home (extrapolating the annual cost for all food by reference to the daily cost for food prepared and eaten at home). ${ }^{109}$

\footnotetext{
106 For each of the items in this paragraph, see CES, supra note 86, at 10-11.

107 See id. at 235.

108 See id. at 22.
}

109 As an interesting aside, the CES found that, expressed in percentage terms, the expenditure share for food is greater for husband-and-wife-only consumer units $(13.2 \%)$ than for those with young children $(11.5 \%)$. The researchers attribute this difference to a decline in eating outside the home, as parents of young children might not eat outside the home as often as, or in restaurants as expensive as, couples without children. See ANTHOLOGY, supra note 55, at 35, 37. Using only the data for in-home eating and extrapolating the annual costs from that data would ensure that the couple with young children is not penalized (or, phrased alternatively, that the childless couple is not unduly favored). "The expenditure shares for food at home are roughly equivalent for husband-and-wife consumer units (7.5 percent) and households with children under 6 years of age ( 7.2 percent). However, the former allocate 5.7 percent of total spending to food away from home while the latter 
As before, the food portion of the taxpayer's Nondiscretionary Deduction would be a specified percentage (say, $40 \%$ ) of the amount determined for the appropriate household size. As with the shelter component of the Nondiscretionary Deduction, the taxpayer would simply look up the proper amount in a table prepared by the government. Only taxpayers who are eligible to deduct the shelter component of the Nondiscretionary Deduction would be eligible to take the food portion of the Nondiscretionary Deduction. This would prevent teenagers living at home with earnings from a part-time job from deducting the costs of food, since his or her parent or parents would deduct the proper amount for the entire household. ${ }^{110}$

\section{Transportation}

Essential transportation costs should also be considered nondiscretionary. Overall, "[t]ransportation costs make up a large part of a consumer's budget," and data from the year 2000 "indicate that 88 percent of all consumer units either owned or leased a vehicle, and expenditures for leasing and purchasing... vehicles made up almost 10 percent of the average consumer unit's total expenditures." 111

Data collected by the Consumer Expenditure Survey describe the average costs for vehicle purchases for the year for all households, vehicle expenses (such as maintenance and repair costs and insurance), and the costs of public transportation. Since not all households purchased a car in the survey year, the average purchase cost for households in the median quintile $(\$ 7,538)$ would grossly understate the average cost for those households that actually bought a car or truck. Similarly, the average cost for public transportation for households in the median quintile $(\$ 275)$ would understate the average cost of those households relying primarily on public transportation. The average cost of maintenance and repairs for those in the median quintile $(\$ 698)$ is probably pretty close to the national median for car-owners, since $88 \%$ of households own or lease a car. The same is probably true of car insurance costs $(\$ 826) .{ }^{112}$

One might initially suggest that the best figure to use for purposes of the transportation portion of the Nondiscretionary Deduction

\footnotetext{
allocated just 4.3 percent." Id. at 37 n.10.

${ }^{110}$ See supra note 93.

111 Laura Paskiewicz, The Cost and Demographics of Vehicle Acquisition in ANTHOLOGY, supra note 55, at 61 (citations omitted).

${ }^{112}$ For each of the items in this paragraph, see CES, supra note 86, at 11-12 tbl. 1.
} 
might be a specified percentage (say, $40 \%$ ) of the annual lease cost of a 3- or 4-year old median-priced American model automobile, plus the median annual maintenance, insurance, and gasoline costs. The costs associated with a newer or more expensive model of car or truck could reasonably be considered discretionary. Alternatively, the transportation portion of the Nondiscretionary Deduction could use the median annual cost of public transportation for those households relying primarily on public transportation. Because public transportation is not readily available in many locales in the United States, however, it surely would not be accurate to say that using private transportation is more often than not a discretionary choice.

The most difficult issue in connection with transportation costs would be the adjustment for household size, and this difficulty might implicate the choice above regarding whether to use the lease cost of a car or the costs of public transportation. Consumer Expenditure Survey data shows that the average total transportation costs, in the aggregate, do differ by household size. For example, the average total cost for one-person households is $\$ 4,012$, while the average cost for households containing five or more persons is $\$ 11,123$. $^{113}$ (These numbers do not reflect medians but rather the average for all households and include outlays in addition to lease costs, maintenance, gasoline, and insurance.) These differences might arise, for example, if a household contains a dependent teenager with his or her own car to drive to a part-time job as well as a car for each adult. The difficulty here is gleaning whether the ownership of multiple cars is reasonably considered "discretionary" or whether each filing household should be limited to the deduction associated with only one car.

For this reason, the transportation portion of the Nondiscretionary Deduction might be best defined, after all, by a specified percentage (say, $40 \%$ ) of the annual median cost to a single adult individual who uses primarily public transportation. A married couple filing jointly would be entitled to two shares, while single individuals would be entitled to one, with half shares allocated for each dependent in the household. ${ }^{114}$ I find this to be the least satisfying result of the Nondiscretionary Deduction portions discussed so far (shelter, food, and transportation), but administrative necessity

113 Id. at 23 tbl. 4.

${ }^{114}$ As with the shelter and food portions of the Nondiscretionary Deduction, the teenager living at home with earnings from a job would not get the deduction; it would go to the parent or parents. 
may not provide a reasonable alternative.

\section{Apparel}

The 2000-2001 Consumer Expenditure Survey lists the average annual costs of apparel for men aged sixteen and over, for boys aged two to fifteen, for women aged sixteen and over, for girls aged two to fifteen, for children under two, and in the aggregate. ${ }^{115}$ It also lists the same information for households of various size. For example, households containing one person paid on average $\$ 862$ for apparel, while households containing five or more persons paid on average $\$ 2,893$. $^{116}$

The apparel portion of the Nondiscretionary Deduction should be a specified percentage (say, $40 \%$ ) of the median apparel costs for households of varying sizes, as described above.

\section{E. Work Expenses}

Professor Zelenak's article discussed earlier recommended adopting an Earned Income Deduction to account for the increased expenses incurred by workers. His recommended deduction would account for the expenses associated with commuting, work clothes, and meals at work. ${ }^{17}$ What about child-care expenses for the single working parent or the two-earner married parents? Because he concludes that "the tax treatment of child care expenses is best analyzed in the context of the overall income tax treatment of families with children," he declared the expenses to be outside the scope of his article. ${ }^{118}$

Because the Nondiscretionary Deduction already includes components pertaining to the median costs of transportation, apparel, and food, allowing an add-on deduction for workers would likely be "double counting" to some extent. This is not entirely true; I specifically suggested, for example, that the food component should be calculated by using only the cost of food prepared at home. And the "median" data concerning transportation and apparel costs would contain not only workers (leading to double counting) but also nonworkers, so the "median" may be weighted on the low side for a

115 See CES, supra note 86 , at 11 . The survey also lists the cost of footwear. See id.

116 See id. at 23 tbl. 4.

117 Zelenak, supra note 23, at 45.

${ }^{118}$ Id. at 48. 
full-time worker. Nevertheless, because the Nondiscretionary Deduction does contain explicit allowances for specified percentages of transportation, apparel, and food costs for the median taxpayer, it seems less pressing to allow an add-on deduction for workers with respect to these expenses.

With respect to the costs of child (and other dependent) care, however, I think the Nondiscretionary Deduction approach may be fruitful. Currently, section 21 provides a tax credit for specified portions of dependent-care expenses incurred because of work, and section 129 allows exclusion of certain employer-provided dependent care. ${ }^{119}$ Because amounts spent on child and dependent care in order to allow one to work could reasonably be considered "nondiscretionary" costs, the section 21 credit could be replaced by a deduction (another component of the taxpayer's Nondiscretionary Deduction) equal to a specified portion (say, $40 \%$ ) of the median costs incurred for such care. It would be a deduction, rather than a credit, because it defines and refines the tax base premised on "discretionary income." Tax-base defining outlays are usually cast in the form of deductions, while credits are typically used only in the case of pure tax expenditures. ${ }^{120}$ As with the other components of the Nondiscretionary Deduction, the taxpayer would simply look up the appropriate amount from a table containing empirical data regarding the median costs for the care of the appropriate number of dependents.

As with the shelter component of the Nondiscretionary Deduction, the taxpayer would have to retain records indicating that amounts were, indeed, spent on child care costs. Perhaps the taxpayer would need to show that a specified statutory minimum was spent to be entitled to any deduction; if the minimum was spent, the median cost would be allowed, whether the amount actually spent was higher or lower.

\section{F. Education}

In addition to the tax benefits aimed at education providers (such as the possibility of tax exemption under section $501^{121}$ and the ability to receive deductible charitable contributions under section $170^{12}$ ), there are a panoply of tax subsidies aimed at individuals who are

\footnotetext{
119 See I.R.C. $\$ \$ 21,129$.

${ }^{120}$ See supra note 92.

121 See I.R.C. § 501.

${ }^{122}$ See I.R.C. $\$ 170$.
} 
saving or paying for higher education. ${ }^{123}$ Tax benefits for current expenses include the Hope and Lifetime Learning Credits, ${ }^{124}$ exclusion of certain employer-provided education assistance, ${ }^{125}$ and the exclusion for qualified scholarships and tuition reductions. ${ }^{126}$ Taxfavored savings vehicles for higher education include so-called section 529 plans, ${ }^{127}$ Coverdell education savings accounts, ${ }^{128}$ and education savings bonds. ${ }^{129}$ In addition, student loan interest can generally be deducted, ${ }^{130}$ and certain student loan forgiveness can be excluded. ${ }^{131}$ The five-year tax expenditure total for these provisions for 2004 through 2008 is estimated to be nearly $\$ 50$ billion. ${ }^{132}$

The extent to which the costs of higher education should be considered "discretionary" or "nondiscretionary" is debatable. These costs are inherently different from the costs of shelter and food, which must be incurred to live in a humane and dignified manner. Millions of adults with only a high-school education lead productive and satisfying lives in jobs that provide a living wage. However, these jobs are decreasing over time, with employers increasingly looking for additional analytical, writing, and technology skills obtained chiefly through higher education. Does this mean that the costs of higher education should be considered "nondiscretionary" to some extent today? Ultimately, that determination is for Congress to make. If Congress resolves this question in the affirmative, then the question becomes how to implement that decision within the Nondiscretionary Deduction mechanism set forth in this article. ${ }^{133}$

123 See generally STAFF OF JOINT COMM. ON TAXATION, 108Th CONG., PRESENT LAW AND ANALYSIS RELATING TO TAX BENEFITS FOR HIGHER EDUCATION, JCX-5204 (July 21, 2004) [hereinafter JCT EDUCATION] (describing and analyzing the various tax subsidies).

${ }^{124}$ See I.R.C. \$ 25A.

${ }^{125}$ See I.R.C. $\$ 127$.

${ }^{126}$ See I.R.C. $\$ 117$. In addition, Treas. Reg. $\$ 1.162-5$ details when education costs can be deducted as an ordinary and necessary business expense.

127 See I.R.C. § 529.

${ }^{128}$ See I.R.C. $\$ 530$.

${ }^{129}$ See I.R.C. $\$ 135$.

${ }^{130}$ See I.R.C. $\$ 221$.

131 See I.R.C. § 108(f).

${ }^{132}$ See JCT EdUCATION, supra note 123, at 2.

133 If Congress concludes that spending on higher education is discretionary, it may still make a non-tax policy decision to subsidize higher education for other reasons, such as the perceived positive externalities for society at large. Tax expenditure evaluation generally entails cost-benefit analysis. For instance, is the tax subsidy an efficient mechanism to produce the non-tax benefit sought? Is the aim of 
If the costs of higher education are to be considered "nondiscretionary," then the amount that should be allowed as a component of the Nondiscretionary Deduction should be computed in a manner that is different from the manner described above for other components of the Nondiscretionary Deduction. For other items, I recommended that a specified percentage of the median costs spent by households of varying sizes be used to define the deduction amount. With respect to education costs, however, that approach would allow the costs of private education to affect the median. Instead, I would key the amount allowed to the average cost of public colleges and universities on the reasonable assumption that a decision to attend a private rather than a public institution is surely discretionary.

Tuition and fees at both public and private colleges and universities have generally risen faster than the rate of inflation since 1981, due in part to decreasing levels of government funding for higher education. ${ }^{134}$ For the 2002-2003 academic year, the average cost of tuition and fees at four-year private colleges and universities was $\$ 16,948$, at four-year public institutions was $\$ 4,059$, at two-year private colleges was $\$ 10,755$, and at two-year public colleges was $\$ 1,479 .^{135}$ In 2001 , approximately $61 \%$ of college students were enrolled in four-year institutions, and $77 \%$ of college students were enrolled in public institutions. ${ }^{136}$

For students enrolled full-time in a degree-granting program at a four-year institution, they (or their parents, but not both) would be allowed to deduct (as a component of their Nondiscretionary Deduction) a specified amount (say, $40 \%$ ) of the average tuition and

the tax benefit to provide a subsidy (transfer to needy) or an incentive (effect change in behavior)? In either case, what is the optimal design for the policy to be effective, without providing undue windfalls (benefits for behavior that taxpayers would engage in anyway)? Is the tax system the best vehicle to implement the policy? Would we care if the tax benefits are captured by educational institutions, which may raise tuition costs and fees if they are deductible or creditable? Does it matter what the institutions do with the extra cash , e.g., to provide more scholarships to needy students or to raise professors' salaries? Do we care about progressivity considerations? Do we care that many people who go to college would have gone even without the tax benefit? Do we care that the most needy students and parents are outside the tax system? And so on.

${ }^{134}$ See JCT EDUCATION, supra note 123, at 35 ("Federal funds have remained relatively constant, State and local funding has declined, tuition and fees have increased, and other funding has increased modestly.").

${ }^{135} I d$.

${ }^{136} I d$. 
fees for four-year public institutions $(\$ 4,059$ for $2002-2003){ }^{137}$ For those enrolled full-time in a degree-granting program at a two-year institution, the amount would be keyed to the average tuition and fees for two-year public institutions $(\$ 1,479$ for $2002-2003)$. For those enrolled part-time, the allowance would be reduced by half. Since the decision to go on to graduate school can fairly be considered "discretionary," no deduction would be allowed for post-graduate education in the Nondiscretionary Deduction. In addition, no deduction would be allowed to the extent that expenses are paid for with withdrawals from the tax-preferred savings vehicles available under current law (or by an excludable scholarship). The Hope and Lifetime Learning Credits in section 25A would be repealed.

\section{G. Health Care}

As with education costs, the Code contains a panoply of provisions dealing with health care costs, including the exclusion for employer-provided health care and health insurance, ${ }^{138}$ the deduction of health insurance costs by the self-employed ${ }^{139}$ the deduction of medical expenses (including health insurance paid by employees who are not provided health insurance by their employers) to the extent that they exceed $7.5 \%$ of the taxpayer's Adjusted Gross Income, ${ }^{140}$ and health savings accounts. ${ }^{141}$ The latter allows the taxpayer to establish a savings account with before-tax dollars on which the earnings are also excluded to the extent used to pay for medical expenses. ${ }^{142}$ In order to establish the account, the taxpayer must obtain a high-deductible insurance policy satisfying various criteria.

Some (though not all) health care costs could certainly be considered "nondiscretionary" in the sense used in this article. Unlike education, certain health care interventions are necessary for life to continue. For that reason, the costs of some medical care are like the costs of basic sustenance. But the approach taken in this article for other nondiscretionary costs would seem inappropriate for the costs of

${ }^{137}$ Room and board would not factor into the deduction because the shelter and food components of the Nondiscretionary Deduction account for them already.

138 See I.R.C. $\$ 106$.

139 See I.R.C. $\S 162(l)$.

140 See I.R.C. $\$ 213$.

141 See I.R.C. $\$ 223$.

${ }^{142}$ Thus, the taxpayer receives better than consumption-tax treatment (both expensing of the investment, as under a cash-flow consumption tax, and exclusion of the investment returns, as under a wage tax). 
health care. With respect to shelter or food, for example, one can persuasively argue that costs incurred above the median are fairly considered "discretionary" and thus should not enter into the Nondiscretionary Deduction. Health care, however, is different by its very nature. The cost of a triple bypass operation for a particular taxpayer may well result in an outlay far above the overall median health care costs for the comparable household for the year. But it is extremely doubtful that the amount spent above the median for the open-heart surgery could be fairly considered spent purely by choice in the same sense that food or housing costs in excess of the median can be said to be "discretionary." The approach taken in current section 213, which allows deduction of all costs above $7.5 \%$ of the taxpayer's Adjusted Gross Income ${ }^{143}$ may actually be a better approach to defining "nondiscretionary" outlays in the unique context of health care costs. At the same time, I should stress that this approach (allowing a deduction to the extent outlays exceeded a defined percentage of Gross Income or Adjusted Gross Income) would clearly not be appropriate in determining the other components of the Nondiscretionary Deduction, as it would allow deduction of amounts that surely could fairly be categorized as "discretionary." Health care simply seems to be different in kind.

In any event, this very difference, as well as the extremely difficult policy conundrums that extend far beyond the tax world raised by our health-care financing system, suggest that comprehensive tax treatment of health care costs is beyond the scope of this article.

\section{H. Charitable Contributions}

Charitable contributions are deductible to the extent provided in section 170. A person taking the Standard Deduction instead of the collection of Itemized Deductions is not allowed to deduct charitable contributions separately, though the Standard Deduction presumably represents in part the average taxpayer's charitable contributions.

${ }^{143}$ As discussed in Section $\mathrm{K}$, infra, the Nondiscretionary Deduction approach would make possible the elimination of the distinction between Itemized and Abovethe-Line deductions, with its concomitant notion of Adjusted Gross Income. Section 213 could be amended to allow deduction of amounts expended in excess of a defined percentage of Gross Income (or Gross Income less the Nondiscretionary Deduction).

For reasons similar to those discussed with respect to health care, I do not recommend that the personal casualty loss deduction in sections $165(\mathrm{c})(3)$ and $(\mathrm{h})$ be folded into the Nondiscretionary Deduction. 
The charitable contribution deduction should not be subsumed within the Nondiscretionary Deduction but should remain as a separate deduction that is defined by the actual amount contributed to charity. The reason for this treatment is that this deduction is primarily intended to change behavior by encouraging ever-larger gifts to charity, which in part can replace government spending and, even where it does not (e.g., contributions to churches), is also thought to produce sufficient positive externalities to warrant the behavioral incentive. Allowing deduction for only the median contributions for households of varying sizes (and denying deduction for amounts in excess of the median) would be inconsistent with the deduction's very premise. That is not to say that serious reform of the deduction is unnecessary. ${ }^{144}$ It is sufficient for this article, however, to note why collapsing the charitable contribution deduction into the Nondiscretionary Deduction is not appropriate.

\section{Retirement Savings (Outside Social Security)}

As briefly described in Part II, tax-preferred retirement savings vehicles include (among some lesser-used plans) the exclusion or deduction for contributions to qualified pension plans, ${ }^{145}$ so-called section $401(\mathrm{k})$ and $403(\mathrm{~b})$ plans, ${ }^{146}$ and IRAs. ${ }^{147}$ The contributions to these plans are excludable or deductible, and withdrawals are includable. In other words, these are cash-flow consumption tax provisions. Contributions to so-called Roth IRAs ${ }^{148}$ are also taxpreferred, though in a different way. The contribution to the account is not deductible, but all earnings are excludable when withdrawn, as under a wage tax. Each of these tax-preferred retirement savings vehicles have ceilings that limit the amount that can be contributed each year. In this way, the more favorable cash-flow consumption tax or wage tax treatment applies to the retirement savings of the middle and lower classes but does not allow the truly wealthy, who have sufficient discretionary income to save in amounts far in excess of the various ceilings, to shelter all of their savings from tax. Indeed, I argued in Part II that this system is a persuasive illustration of the value implicitly underlying the tax base of the current Code: that

${ }^{144}$ See, e.g., Gene Steuerle, $A$ Win-Win Option for Charity and Tax Policy, 107

TAX NOTES 361 (2005) (surveying several common-sense reform options).

${ }^{145}$ See I.R.C. $\$ \S 401-418 \mathrm{E}$.

${ }^{146}$ See I.R.C. $\S \S 401(k), 403(b)$.

${ }^{147}$ See I.R.C. $\$ 219$.

148 See I.R.C. § 408A. 
discretionary income ought to be fully taxed but that nondiscretionary income, which represents amounts not fairly available for contribution to the fisc, should be protected. Under a pure "income" tax, all savings would be taxed - even the retirement savings of the poor and middle classes. Under a pure "consumption" tax, no savings - even the discretionary savings of the truly wealthy - would be tapped. The current compromise illustrates our desire to protect and encourage the middle and lower classes to save for their retirement (by extending more favorable consumption or wage tax treatment to those savings) because such savings, even though they would be currently taxed under an "income" tax, fairly represent "nondiscretionary" income. At the same time, we wish to tax the large savings pools of the wealthy that exceed the prescribed ceilings (as under a true income tax) because those savings fairly represent "discretionary" income.

Like the charitable contribution deduction, these provisions depend on the behavioral incentive-here, to save specifically for retirement. Even if the aggregate level of savings is not increased in the middle class because of these provisions, there is likely shifting from taxable savings accounts to these tax-preferred accounts. Because these preferred accounts generally cannot be tapped before retirement age without severe tax penalties, they likely succeed in protecting some savings for retirement that would otherwise suffer early withdrawal for pre-retirement consumption. For this reason, these retirement savings provisions should also not be subsumed within the Nondiscretionary Deduction but should remain separate and keyed to actual contributions. Allowing deduction for only the median contributions for households of varying sizes (and denying deduction for amounts in excess of the median) would pervert the deduction's individual behavioral incentive to save to the maximum allowed under the applicable ceiling.

\section{J. State and Local Income and Sales Taxes and Federal Payroll Taxes}

Real estate property taxes paid by homeowners would be subsumed within the shelter component of the Nondiscretionary Deduction, as described earlier. How should state and local income, sales, and personal property taxes be treated?

State income taxes are mandatory extractions imposed by state and local governments and thus could be considered "nondiscretionary" at least to some extent. Sales taxes on luxury items can clearly be considered "discretionary" outlays because the 
purchase of luxury items is itself a discretionary choice. The purchase of basic necessities, such as food and shelter, may not be considered discretionary, but these purchases are also often free of state and local sales tax. Some states also impose personal property taxes, such as on automobiles. Finally, some states choose to substitute sales taxes for income taxes, a decision that prompted the 2004 enactment to allow taxpayers to deduct either their state and local income taxes or sales taxes (but not both). ${ }^{149}$

The Nondiscretionary Deduction should contain a separate component for state and local taxes (other than real property taxes) paid by individuals. It should equal a specified portion (say, $40 \%$ ) of the median state and local tax (other than real property taxes) paid by households of various sizes, as described above for other components of the Nondiscretionary Deduction. As I recommended with respect to the shelter component of the Nondiscretionary Deduction, my primary recommendation would be to allow a single median (for each household size) for taxpayers across the country. Also as described earlier, state-by-state tables could be computed, instead, if political necessity dictates, or low- and middle-income taxpayers in specific high-tax localities could be allowed to deduct a higher "specified percentage" of the national median. Allowing the national (or state) median of state and local taxes to govern the amount deducted, regardless whether they take the form of income, sales, or personal property taxes, avoids what may be seen as an inappropriate (from a federalist perspective) entanglement of the federal government in the decision of states regarding how best to raise revenue.

What about federal payroll taxes? In an earlier article, ${ }^{150} \mathrm{I}$ argued that the employee portion of the payroll tax burden on labor income ought to be explicitly integrated with the income tax burden on labor income, and I explored the various means of accomplishing that. I argued that the payroll tax (composed primarily of the Social Security and Medicare taxes) was a true "tax" and that imposing two federal taxes on labor income masks the higher federal effective combined tax rate on the labor income of the lower and middle classes. This is particularly true since the payroll tax, unlike the income tax, has no Personal Exemption Deduction or Standard Deduction that protects a certain amount of nondiscretionary income from taxation (though I did not use the rubric of "discretionary" and "nondiscretionary" back

149 See I.R.C. \$ 164(b)(5) (which expired at the end of 2005).

${ }^{150}$ See Deborah A. Geier, Integrating the Tax Burdens of the Federal Income and Payroll Taxes on Labor Income, 22 VA. TAX REV. 1 (2002). 
then); the first dollar earned is taxed.

I recommended that employees be permitted to deduct from Gross Income under the income tax a portion of payroll taxes paid (equal to a reasonable Personal Exemption amount, representing nondiscretionary income). ${ }^{151}$ Under the view that the earlier payment was a true "tax," later receipt of cash Social Security payments in retirement would be fully includable, contrary to current law (though the value of medical care received in kind under the Medicare program would not be included, as under current law). The taxpayer's Nondiscretionary Deduction in retirement would protect that portion of the cash payment that is fairly considered nondiscretionary income, which may well be all of it. But to the extent that it is considered discretionary income because it is not sheltered by the Nondiscretionary Deduction, or other deductions, it should be taxed.

Because of the income tax revenue that would be lost, however, I conceded in 2002 that adoption of my recommendation was politically unlikely. I therefore suggested (and recently reiterated ${ }^{152}$ ) that a politically achievable alternative might be to raise the Social Security tax wage ceiling, currently set at $\$ 94,000$, and slash the marginal rates as low as possible to retain revenue neutrality, while retaining the payment formula as it is today. With lower marginal rates, the multiple tax burden on the labor income of the lower and middle classes would not be as problematic. On the other hand, if done in conjunction with the kind of far-reaching changes recommended in this article, direct integration of the two taxes might well be possible.

\section{K. Final Thoughts on the Nondiscretionary Deduction}

The Nondiscretionary Deduction proposed here would be, some might argue, nothing more than a refined Standard Deduction conflated with the Personal and Dependent Exemption Deductions and the Child Tax Credit. In one sense, they would be right, if the role of those Deductions and Credit is chiefly to exempt from taxation amounts not fairly available for contribution to the fisc, even though spent on consumption. But the form of the proposed Nondiscretionary Deduction is important for three reasons.

${ }^{151}$ Alternatively, I argued that a portion of the employee payroll tax could be credited against the income tax. See id. at 56-64 (discussing both the deduction and credit alternatives).

${ }^{152}$ See Deborah A. Geier, The Payroll Tax Liabilities of Low- and MiddleIncome Taxpayers, 106 TAX NOTES 711 (2005). 
The first is one of cognitive perceptions. Explicitly identifying the various components of the Nondiscretionary Deduction, such as the shelter component, the state and local tax component, the food component, etc., and having taxpayers sum up their allowable portions based on the number of dependents by looking at tables for each type of component, explicitly battles perceptions that "no deduction is allowed for" housing, state and local income and sales taxes, etc., which can erode support for the tax base. This is important in creating a shared support for the system and its underlying premises.

For instance, renters commonly complain that they are unfairly provided no "tax break" for their shelter expense, and those who take the Standard Deduction routinely complain that they are denied a tax reduction for their charitable contributions. Indeed, proponents of the "flat tax" (which, at the individual level, would tax only labor earnings above a Standard Deduction amount) routinely state that "no deductions" for any outlays would be allowed. Of course the current Standard Deduction and Personal and Dependent Exemption Deductions combine to free from taxation an amount that presumably represents an arbitrary fixed amount for shelter for the renter, charitable contributions for the non-Itemizer, etc., and the same could be said of the Standard Deduction that would accompany a "flat tax" of the Hall/Rabushka type. ${ }^{153}$ These allowances are, however, "hidden" in a bland "Standard Deduction" or "Personal and Dependent Exemption Deduction," which to the typical taxpayer means nothing. It is easy to fall into the trap of thinking that "no tax allowance" is recognized for a particular outlay unless it is specifically identified: "the home mortgage interest" deduction, the deduction for "state and local taxes," the "charitable contribution" deduction. Those that take the Standard Deduction come to think that none of their costs are being recognized by the tax system as ones that should legitimately reduce the tax base. Creating a Nondiscretionary Deduction for each taxpayer that explicitly allows the taxpayer to deduct from the tax base specified percentages of the median outlays for shelter, food, state and local income and sales taxes, etc. - each explicitly identified as such and explicitly modified to take into account the number of dependents in the household - would reinforce the point that the tax system takes into account the taxpayer's real cost of living. It would also concomitantly reinforce the notion that amounts spent above the median are on "the

153 See Robert E. Hall \& Alvin Rabushka, The Flat TaX vii (2d ed. 1995). 
taxpayer's dime" and not "the government's dime."

Second, the current Standard Deduction, Personal and Dependent Exemption Deductions, and Child Tax Credit are composed of arbitrarily selected amounts that do not pretend to have any connection to empirical data. In contrast, the Nondiscretionary Deduction would reflect empirical data regarding the actual median costs of the component items and would be updated every few years to reflect changes in the data. Thus, the tax system would address the concern voiced by Elizabeth Warren and Amelia Warren Tyagi that the tax system should explicitly take account of the changing amounts of "discretionary" income available to households over time.

Third, adoption of the Nondiscretionary Deduction would allow the simplification of eliminating the distinction between "Above-theLine Deductions" and "Itemized Deductions" (and the concomitant concept of "Adjusted Gross Income"). With the adoption of the Nondiscretionary Deduction to take the place of several Itemized Deductions, the Standard Deduction, the Personal and Dependent Exemption Deductions, and the Child Tax Credit, there would no longer be any need to differentiate among the different kinds of deductions. The taxpayer would simply take his or her Nondiscretionary Deduction and any other deduction (such as the alimony deduction, the charitable contribution deduction, or incomeproducing deductions) to which the taxpayer may be entitled.

Under current law, all taxpayers are permitted to take the socalled Above-the-Line Deductions listed in section 61 directly from Gross Income, without limit, which produces Adjusted Gross Income. In addition, the taxpayer is entitled to take the Personal and Dependent Exemption Deductions, as well as either the Standard Deduction or the total of the taxpayer's Itemized Deductions, including the home mortgage interest deduction, the deduction for state and local taxes, and the charitable contribution deduction. Several of these Itemized Deductions are subject to further limit under sections 67 and 68 . The latter, which is currently scheduled to expire in 2010 (though it will be revived without further congressional action in 2011), limits the amount of aggregate Itemized Deductions (other than the medical expense deduction, the deduction for investment interest, and the deduction for certain casualty, theft, or gambling losses) that can be deducted by high-income taxpayers. Section 68 was never really anything more than a backdoor marginal rate increase for high-income taxpayers, which should be more forthrightly done (if it is to be done at all) directly in the section 1 rate schedules. Section 67 provides that all Itemized Deductions not listed 
in section $67(\mathrm{~b})$ are deductible only to the extent that their aggregate exceeds $2 \%$ of the taxpayer's Adjusted Gross Income (the amount of Gross Income less the taxpayer's Above-the-Line Deductions). The primary deductions that are subject to the so-called $2 \%$ floor are most unreimbursed employee business expenses under section 162 , expenses and depreciation under sections 212(1), (2) and 168 (and related sections) attributable to investment property other than those producing rents and royalties, the costs of tax-preparation fees and related expenses in section 212(3), and the so-called Hobby Loss Deduction in section 183(b). If Congress wished to continue this limit, it could easily do so by enacting a specific provision that lists these particular deductions and provides that they are deductible only to the extent that they, in the aggregate, exceed a specified percentage of Gross Income (or Gross Income less the taxpayer's Nondiscretionary Deduction). ${ }^{154}$

The final recommendation in this section is not necessarily linked to the Nondiscretionary Deduction, but this is as good a place as any to say it: the Alternative Minimum Tax (AMT) should be repealed. ${ }^{15.5}$ With the recasting of the tax base described in this article (and the adjustment to the tax rate schedules that the new base would allow), it would be an ideal time to take care of the AMT ticking time bomb. ${ }^{156}$ To the extent that the adjustments and preferences listed in sections 56 and 57 are considered important to the definition of the tax base (e.g., taxing the interest from private activity bonds not funding essential governmental services, reducing the rate of accelerated

${ }^{154}$ Similarly, the medical expense deduction in section 213 adopts a $7.5 \%$-of-AGI floor, and the personal casualty and theft deduction in section $165(\mathrm{~h})(2)(\mathrm{A})$ adopts a $10 \%$-of-AGI floor. Each could adopt a floor using Gross Income (or Gross Income less the taxpayer's Nondiscretionary Deduction).

${ }^{155}$ See, e.g., STAFF OF JOINT COMM. ON TAXATION, 107TH CONG., 2 STUDY OF THE OVERALl STATE of THE FEDERAL TAX SySTEM AND RECOMMENDATIONS FOR Simplification, Pursuant to Section 8022(3)(B) of the Internal Revenue CODE OF 1986, JCS-3-01, at 2-22 (2001) (recommending repeal).

${ }^{156}$ It has been estimated that, by $2010,92 \%$ of taxpayers earning between $\$ 100,000$ and $\$ 500,000$ will be subject to the AMT, $73 \%$ of households with income between $\$ 75,000$ and $\$ 100,000$ will owe AMT, and households with income of less than $\$ 100,000$ will account for $52 \%$ of AMT taxpayers in. See Leonard E. Burman, William G. Gale \& Jeffrey Rohaly, The AMT: Projections and Problems, 100 TAX NOTES 105 (2003). Enacted in 1969 when Congress learned that 155 millionaires had avoided paying any income tax the prior year, the AMT, which essentially requires taxpayers to compute tax under the regular income tax and the AMT and pay whichever is higher, has become an administrative nightmare and has deviated far from its original goals by reaching the middle class. 
depreciation of certain property, etc.), the changes should be made directly to the relevant sections for all taxpayers.

\section{THE TAXATION OF CAPITAL INCOME}

A bedrock notion implicit in the idea that the tax base should aim at shielding nondiscretionary income from tax while taxing discretionary income under a progressive rate structure is that capital income and labor income should be treated the same. To the extent that labor or capital income falls within the Nondiscretionary Deduction amount, it should escape taxation. To the extent that it exceeds the Nondiscretionary Deduction and other deductions, it should be subject to a progressive rate structure because, while nondiscretionary costs increase as income rises, nondiscretionary costs do not likely rise as fast as income rises. ${ }^{157}$

Suppose, for example, that the Nondiscretionary Deduction for taxpayers $A, B$, and $C$, who have the same relevant status characteristics that determine the amount of their Nondiscretionary Deduction, is $\$ 20,000$. $A$ earns $\$ 40,000$ in salary and realizes $\$ 10,000$ of capital returns outside of qualified retirement accounts, composed of any combination of interest, dividends, and capital gains; $B$ earns $\$ 50,000$ in salary and realizes no capital returns outside of qualified retirement accounts; and $C$ earns no salary but realizes $\$ 50,000$ of capital returns outside of qualified retirement accounts. These three taxpayers have the same $\$ 30,000$ taxpaying capacity after taking into account the Nondiscretionary Deduction. The first $\$ 20,000$ of their aggregate income should be protected from taxation as "nondiscretionary" income, regardless of source, but the remaining $\$ 30,000$ should be subject to tax, at whatever graduated rate structure the political process deems appropriate to raise the desired revenue. The source of the income simply has no bearing on properly measuring the taxpayers' "discretionary income." Reduced taxation on capital income can result in taxpayers with equal amounts of discretionary income, such as taxpayers $A, B$, and $C$, being taxed quite differently, which violates fundamental notions of horizontal equity. ${ }^{158}$

Since World War II, an increasing portion of the aggregate federal tax revenue has been collected from labor income, as opposed

157 See supra Part III.

158 Horizontal equity is achieved when similarly situated taxpayers are taxed alike. Likeness is usually measured by reference to the chosen tax base. If the chosen tax base is "discretionary income," then taxpayers with the same amount of "discretionary income" should pay the same amount of tax. 
to capital income. The chart below shows the aggregate tax collected from each source at the federal level over the years. ${ }^{159}$

Total Tax Receipts, 1929-2002

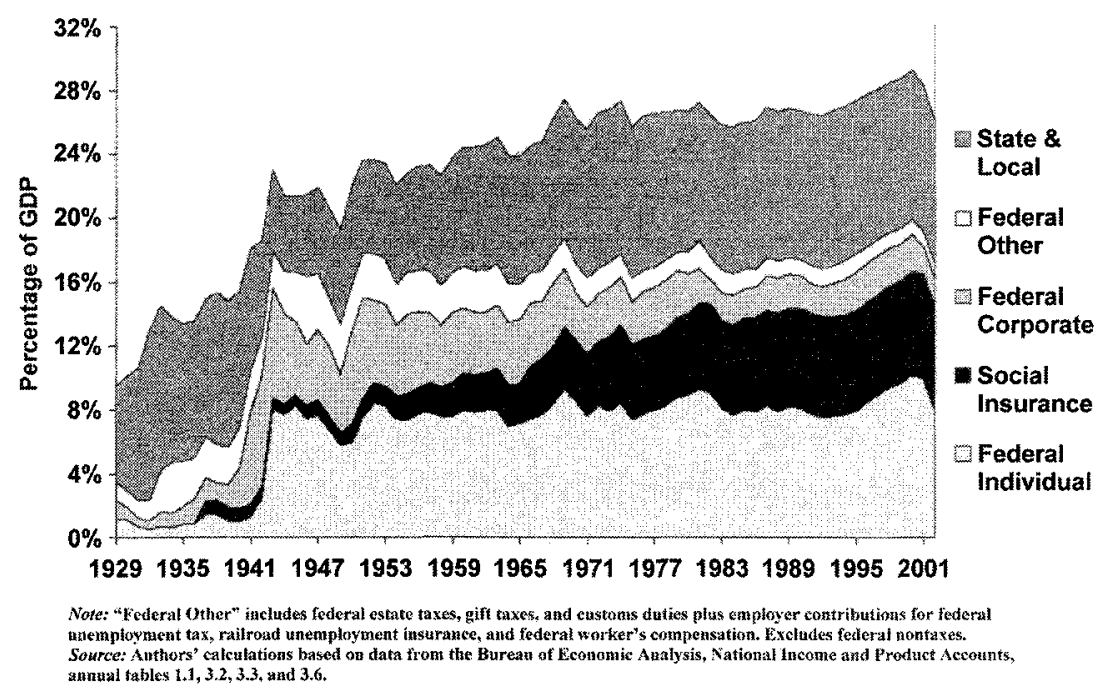

The amount of tax collected under the individual income tax (the bottom slice) has remained fairly constant as a percentage of GDP since WWII (when the income tax first became a "mass tax" instead of a "class tax"). But notice the slice just above that. The payroll taxes - composed chiefly of Social Security and Medicare taxes have increased substantially since WWII and now collect almost as much revenue as the individual income tax. This tax is a tax on labor income only (no capital income is taxed), the first dollar earned is taxed with no exemptions, and as of 2006 , only the first $\$ 94,000$ is taxed under the Social Security tax. ${ }^{160}$ The result is that this portion of the aggregate federal tax burden is borne mostly by lower and middle class wage earners. Notice the next slice on top of that - the corporate tax. While we are uncertain who bears the economic burden of the corporate tax, most economists tend to think that it is borne by all holders of capital, not labor income. ${ }^{161}$ Furthermore, notice the decreasing amounts collected under this tax since WWII. Taken together, it shows that the aggregate federal tax burden, when all federal taxes are considered, has shifted to labor income

159 This chart appears in Adam Carasso \& C. Eugene Steuerle, Changes in Total Government Tax Receipts Since 1929, 100 TAX NOTES 953 (2003).

${ }^{160}$ The income ceiling for application of Social Security taxes increases as average wage rates increase. The Medicare tax is applied to all wages without a ceiling. See Geier, supra note 150 , at 16-18.

161 See, e.g., SLEMROD \& BAKIJA, 3d ed., supra note 69, at 76-79. 
significantly. Indeed, the payroll tax tranche and the corporate tax tranche, summed together, take a fairly constant percentage of GDP since WWII, but the mix between them shifts ever more of the burden away from the corporate tax to the payroll tax.

Moreover, this trend has accelerated in recent years, as evidenced most notably by the reduction in the most common capital gains rate from $28 \%$ to $20 \%$ in 1997 , followed by another $25 \%$ reduction (from $20 \%$ to $15 \%$ ) and the extension of the capital gains rates to most dividend income in $2003,{ }^{162}$ the repeal (at least for now) of the estate tax in 2010, and temporary "expensing" provisions enacted in 2002. Consumption tax advocates are not shy in stating their desires to free capital returns entirely from taxation, effectively taxing only labor income.

The result of the shift in tax burden away from capital income to labor income is that the "super wealthy" can have an overall effective federal tax rate that is lower than those who are "merely wealthy" because capital income is heavily concentrated in the very wealthiest of households. This is particularly true with respect to capital gains, which are extremely concentrated in the wealthiest of households. As

${ }^{162}$ Full and effective integration would be economically efficient, and nothing in this article should be interpreted as a lack of support for integration. But this tax rate reduction for dividend income was substituted for a provision that would have fully integrated the corporate and individual taxes by allowing (1) dividends to be excluded to the extent paid out of income that was fully taxed at the corporate level and (2) a stock basis increase (thus reducing capital gain) to the extent of fully taxed retained earnings. A reduced tax rate for all dividends (and a reduced tax rate for all capital gain, whether realized on corporate stock, real estate, collectibles, etc.) "is a poor substitute for a corporate tax integration plan." SLEMROD \& BAKIJA, 3d ed., supra note 69 , at 276 . While a full discussion of the various corporate tax integration plans is beyond the scope of this article, it's worthwhile to note that the integration form most consistent with a tax on discretionary income at the individual level might be a form of mark-to-market system for publicly traded equity interests in business organizations (such as stock, partnership interests, and interests in limited liability companies) and a pass-through system for all privately held businesses, in whatever organizational form held. Cf. Joseph M. Dodge, A Combined Mark-to-Market and Pass-Through Corporate-Shareholder Integration Proposal, 50 TAX L. REv. 265 (1995). Indeed, the tax revenue lost under integration might well be offset by matching the tax rate on capital gain and dividend income with that imposed on labor income. The troublesome distributional effects of most stand-alone integration plans, see SLEMROD \& BAKIJA, 3d ed., supra note 69 , at 277 , would also be offset by such an equalization of tax rates, as the same members of the wealthy elite would likely both enjoy the benefits of integration and suffer the tax-rate increase on capital income.

Cf. Leonard E. Burman, Taxing Capital Income Once, 98 TAX Notes 751 (2003). Therefore, I think the best political strategy would be to present corporate tax integration as part of the reform package suggested in this article. 
reported by Leonard Burman and Deborah Kobes, for example:

Capital gains become more significant at higher incomes, but even at adjusted gross income (AGI) of $\$ 200,000$ to $\$ 500,000$, they only averaged about 12 percent of income in 2000 .

At very high incomes, however, capital gains dominate. Those with incomes of $\$ 10$ million or more report capital gains equal to 57 percent of total income. For the 400 taxpayers with the highest incomes (AGI exceeding $\$ 86.8$ million), capital gains make up more than 71 percent of income, while wages comprise less than 17 percent. ${ }^{163}$

The chart below indicates dramatically how labor income decreases significantly and capital gains increase significantly as income rises. ${ }^{164}$

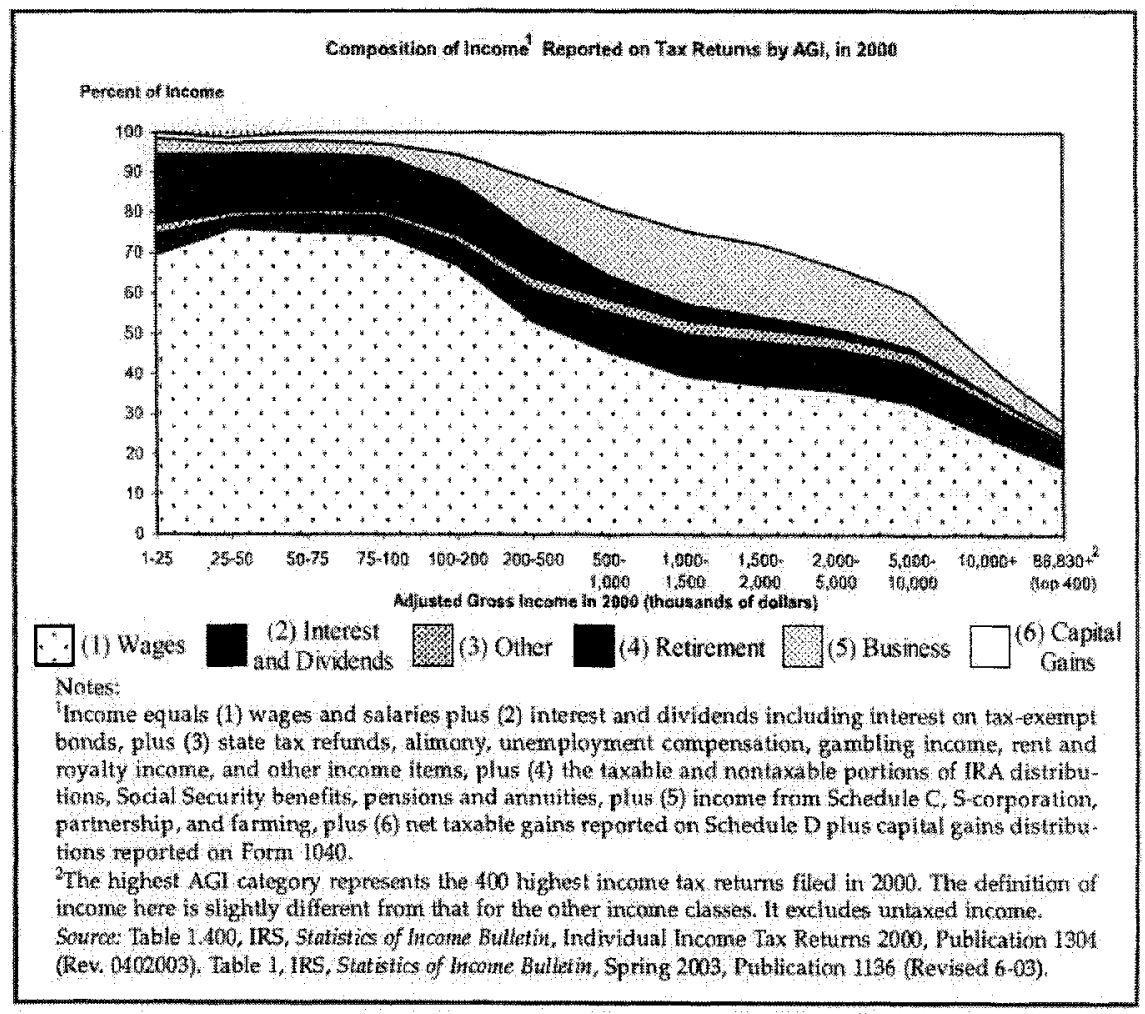

${ }^{16.3}$ Leonard E. Burman \& Deborah I. Kobes, Composition of Income Reported on Tax Returns, 101 TAX NoTES 783 (2003). While they noted that the stock market bubble might have distorted these numbers somewhat, they stressed that earlier data covering 10-year panels shows a similar pattern.

${ }^{164} I d$. 
Here is another view, also including dividend income, showed graphically. ${ }^{165}$

\section{The Wealth Effect}

As taxpayers' incomes rise, so does the percentage of their income from capital gains and dividends.

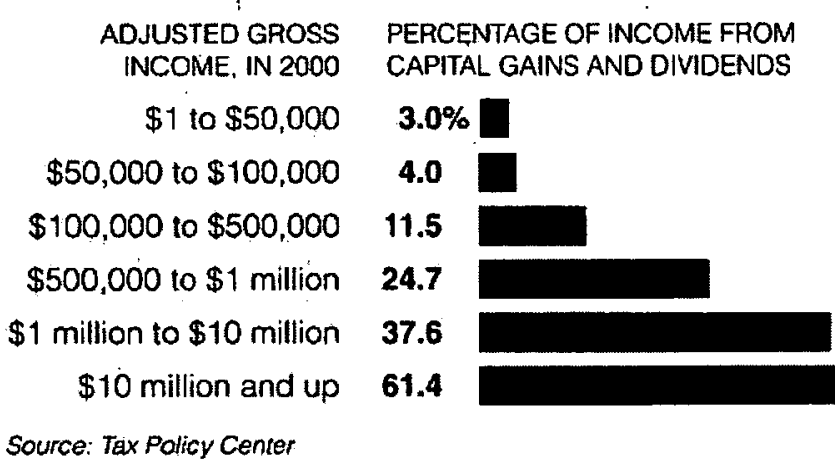

The New York Times

The result, as illustrated in the graph below for the year 2000 , is that those at the very top of the income spectrum can have lower average tax rates than the merely wealthy. ${ }^{166}$

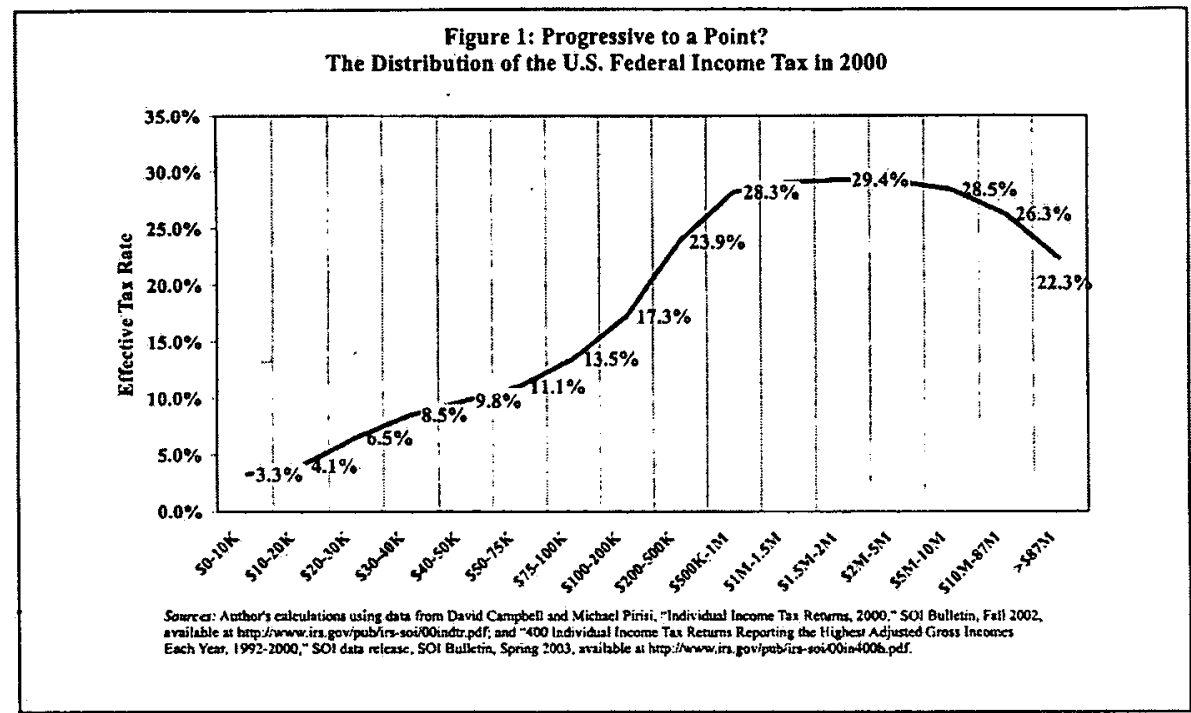

${ }^{165}$ This chart appears in Edmund L. Andrews, A Clash of Goals in Bush's Efforts on the Income Tax: Proposals Would Shift Burden from Wealthy to Middle Class, N.Y. Times, Oct. 6, 2004, at C1.

166 This chart appears in Martin A. Sullivan, The Rich Get Soaked While the Super Rich Slide, 101 TAx NOTES 581, 582 (2003). 
While the above is a snapshot picture of 2000 , when the stock market bubble might have distorted the amount of realized capital gain to a significant extent, the data for the top 400 taxpayers (by AGI) appear to show broad consistency in the amount of capital gains realized as a percentage of overall income. For example, the Service published data on the top 400 from 1992 to $2000 .^{167}$ In 1990 constant dollars, the Adjusted Gross Income threshold for membership in this elite group was $\$ 22,760,000$ in $1992 ; \$ 31,503,000$ in 1996 ; and $\$ 65,880,000$ in 2000 . The percentages of AGI consisting of wages and net capital gain, respectively, as well as their "average tax rate" (total tax paid divided by AGI) were as follows: ${ }^{168}$

\begin{tabular}{|c|c|c|c|}
\hline & $\begin{array}{l}\text { es and Wages } \\
\text { cent of AGI }\end{array}$ & $\begin{array}{l}\text { Net Capital Gain } \\
\text { Percent of AGI }\end{array}$ & Average Tax Rate \\
\hline 1992 & 26.22 & 36.08 & 26.38 \\
\hline 1993 & 16.59 & 48.01 & 29.35 \\
\hline 1994 & 10.15 & 52.26 & 28.57 \\
\hline 1995 & 14.11 & 44.10 & 29.93 \\
\hline 1996 & 11.14 & 63.40 & 27.81 \\
\hline 1997 & 11.76 & 66.76 & 24.16 \\
\hline 1998 & 12.54 & 72.91 & 22.02 \\
\hline 1999 & 14.66 & 72.97 & 22.23 \\
\hline 2000 & 16.70 & 71.83 & 22.29 \\
\hline
\end{tabular}

Notice that the average tax rate dropped significantly beginning in 1997, even before the stock market bubble buildup. This reflected the reduction in the capital gains tax rate from $28 \%$ to $20 \%$ in 1997. These statistics obviously do not reflect the 2003 Act's further reduction in the most common capital gains rate from $20 \%$ to $15 \%$, which presumably would have substantially reduced the average tax rates noted above if this rate had been in effect during these years. ${ }^{169}$

167 STATISTICS OF INCOME Division, I.R.S., THE 400 INDIVIDUAL INCOME TAX Returns Reporting the Highest AdJuSTed Gross Incomes EACH Year, 19922000 , at 8 (Spring 2003), available at http://www.irs.gov/pub/irs-soi/00in400h.pdf.

${ }^{168}$ Id. at 8-9.

169 One might argue, as Joel Slemrod has, that the lower progressivity at the very top may reflect merely a one-time bunched capital gain realization on, say, the sale of a business. See Sullivan, supra note 166, at 581-82. But Martin Sullivan argues that further examination, also taking into account unrealized (and untaxed) appreciation in the assets owned by the wealthiest taxpayers, reduces this concern. See id. at 58283. Moreover, more recent work by Slemrod and his colleague Jon Bakija note that income mobility appears to be decreasing or at least leveling off, concluding: "Since 
Recent evidence for 2003, however, shows the dramatic tax reduction on investment income stemming from the 2003 Act's rate reductions on dividends and capital gains. Taxpayers with income of greater than $\$ 10$ million saw the tax imposed on their dividends and capital gains decrease by an average of $\$ 500,000 .{ }^{170}$

Taking the issue one step further, Peter Orszag has estimated the direct effect of completely exempting capital gains, dividends, and interest from taxation. He found:

The results highlight two key findings. First, the tax cut for most tax units is modest. Only 41 percent of tax units would experience a tax cut. Even in the middle 20 percent of the income distribution, the average tax cut is only $\$ 70$ in 2004 .

Second, high-income households would receive a substantial tax cut. The highest-income 1 percent would receive an average cut of more than $\$ 50,000$ in 2004 . The top one taxpayer in 1,000 taxpayers would receive more than 30 percent of the total tax cut, averaging almost $\$ 300,000$ in $2004{ }^{171}$

Some might argue, however, that the very wealthy still pay a large percentage of the overall tax burden, which ought to be enough to satisfy fairness concerns. For example, data from the Congressional Budget Office shows that the top $1 \%$ of income earners paid $36.5 \%$ of all federal income taxes in 2000 (although, because it paid only $4.3 \%$ of the payroll taxes, the top $1 \%$ paid only $25.6 \%$ of all federal taxes). ${ }^{172}$ But many believe that the amount of tax paid by each income segment is misleading in evaluating the fair distribution of the tax burden. Rather, they argue that trends in pre tax and after-tax income are much more provocative in evaluating the distribution of

the degree of income mobility did not increase from one decade to the next, if 'snapshot' income inequality was increasing over this period, then so too was lifetime inequality." SLEMROD \& BAKIJA, 3d ed., supra note 69, at 67.

${ }^{170}$ See David Cay Johnston, Big Gain for Rich Seen in Tax Cuts for Investments, N.Y. TIMES, Apr. 5, 2006, at A1.

${ }^{171}$ Peter R. Orszag, Exempting Dividends, Interest, and Capital Gains from Taxation, 105 TAX NOTES 1435, 1435 (2004).

172 See Robert GReenstein \& IsaAc Shapiro, CTR. ON BUdget and POL'Y Priorities, The New, Definitive CBO Data on Income and TaX Trends 10-11 (Sept. 23, 2003), http://www.cbpp.org/9-23-03tax.pdf (figures do not include estate and gift taxes, customs duties, and other "miscellaneous sources"). 
the tax burden. Since 1979, the income of the very rich has skyrocketed, while the income of the middle and lower classes has stagnated, and it is this trend that has resulted in the very wealthy paying more tax. ${ }^{173}$

Between 1979 and 2000, the average after-tax income gain of the top $1 \%$ was $\$ 576,400$, while for the middle quintile it was $\$ 5,500$ and for the bottom quintile it was $\$ 1,100 \ldots$ While the average income of those in the 96th to 99th percentiles was $\$ 158,600$ in 2000 (your average successful doctor or lawyer), the average income for those in the top $1 \%$ was $\$ 862,700$. In other words, income earners in the 96 th to 99 th percentiles were much closer to the middle quintile earners than they were to the top $1 \%$, which is truly a class unto itself. $^{174}$

In constant dollars, the income threshold for the top $0.1 \%$ rose to $\$ 710,661$ in 2002 , from $\$ 321,679$ in $1979 . .^{175}$

Ironically, the recent trend described above of shifting the tax burden away from capital income to labor income is directly contrary to the original purpose underlying the adoption of an income tax in the early twentieth century.

Until the twentieth century (except for a brief period of income taxation to fund the Civil War), the federal government raised virtually all of its revenue through various forms of consumption taxes, such as tariffs. Those who debated whether or not to enact an income tax at the end of the nineteenth century and beginning of the twentieth century showed a sophisticated understanding of the

${ }^{173}$ See, e.g., Martin J. McMahon, Jr., The Matthew Effect and Federal Taxation, 45 B.C. L. REV. 993, 994-95 (2004).

174 DODGE ET AL., supra note 4, at 143.

175 See Michael Strudler, Tom PetsKa, \& Ryan PetsKa, FURTHer ANalysis OF THE DISTRIBUTION OF INCOME AND TAXES, 1979-2002, http://www.irs.gov/pub/irssoi/04asastr.pdf. Perhaps one factor contributing to this state of affairs is that the increased national income arising from gains in U.S. productivity has increasingly gone to capital rather than labor, and therefore to wealthy holders of capital. See Louis Uchitelle, Were the Good Old Days That Good?, N.Y. TIMES, July 3, 2005, § 3, at 1 (explaining that "[1]abor's share [of productivity gains], which has historically represented 60 to 65 percent of the total, has fallen in the last five years to the low end of that range" and citing economist Robert Gordon for the proposition that the share taken by capital holders "has increasingly found its way to upper-income families as stock options, dividends, special bonuses and the like"). 
difference between consumption taxation and income taxation and of the regressiveness of consumption taxes. Supporters of income taxation argued that it would more fairly apportion the tax burden by shifting it away from consumption to capital income. ${ }^{176}$

The income tax that was enacted in 1913 was thus specifically aimed at income from capital by establishing personal exemption amounts that were high enough to free most labor income earned by most workers from taxation. So, although it was denominated a tax on "income," it's not too far-fetched to say that it acted primarily as a tax on the capital income of the wealthy. Even Treasury Secretary Andrew W. Mellon, no knee-jerk liberal, argued in the 1920s that earned income ought to be taxed more lightly than capital income. ${ }^{177}$

The reason why the shift to taxing the capital income of the wealthy was thought to be fair was, it can be argued, because that type of income was considered "discretionary," whereas amounts spent on basic consumption were considered "nondiscretionary." Though the specific rubric "discretionary" and "nondiscretionary" was not used, the distinction implicitly infuses the early debates about the fairness of adopting an income tax in the first place. ${ }^{178}$ The implicit assumption evident in the debates surrounding adoption of an income tax is that a tax on capital income more fairly represents a tax on discretionary income than does a tax on consumption. And a tax on consumption can be economically equivalent to a tax on labor income only. ${ }^{179}$

For example, ${ }^{180}$ assume that Jane earns $\$ 100,000$ of wages, that the prevailing average investment return is $10 \%$, that the tax rate is a flat $30 \%$, and that Jane holds her investment for one year before consuming $100 \%$ of everything (principal and investment return). Under'a retail sales tax or a value added tax, Jane would not be taxed

${ }^{176}$ Deborah A. Geier, Incremental Versus Fundamental Tax Reform and the Top 1\%, 56 SMU L. REV. 99, 100 (2003).

${ }^{177}$ Id. at 102 (citing ANDreW W. MEllon, TAXATION: THE PEOPle's Business 93-107 (1924)).

178 See, e.g., Erik M. Jensen, The Taxing Power, the Sixteenth Amendment, and the Meaning of "Incomes," 33 ARIz. ST. L.J. 1057 (2001) (collecting numerous quotations of the day).

179 See DODGE ET AL., supra note 4, at 68-73.

180 These examples are drawn from id. at 72-73. 
on her wages. She would thus have $\$ 100,000$ to invest, which would earn a $10 \%$ return of $\$ 10,000$ under our assumptions. When she spends the $\$ 110,000$ at the end of the year, she would pay a tax of $\$ 33,000$ (30\% of her consumption). Her net return would thus be $\$ 77,000$ ( $\$ 110,000$ less $\$ 33,000)$.

We could create the same net return for Jane if we simply taxed Jane's wages but exempted her investment return from tax. In that case, Jane would pay a $\$ 30,000$ tax on her $\$ 100,000$ of wages, leaving her $\$ 70,000$ to invest. Her $10 \%$ return of $\$ 7,000$ would be free from tax, producing a net return of $\$ 77,000$ - the same as under the retail sales tax above.

Finally, we could also create the same net return under a "cashflow consumption tax," under which all cash flows, including borrowed money, are included in the tax base, and all nonconsumption outlays, such as the purchase of an investment or the repayment of borrowed funds, are deducted. Returning to Jane, for example, her $\$ 100,000$ in wages would be included, but her $\$ 100,000$ investment would be deducted, producing no tax at this point and leaving the full $\$ 100,000$ to invest. The investment would earn a $10 \%$ return of $\$ 10,000$, and when the entire $\$ 110,000$ (principal and investment return) are consumed, Jane would pay tax of $\$ 33,000$, once again leaving a $\$ 77,000$ net return $(\$ 110,000$ less $\$ 33,000)$.

Each of these examples produces a different result than under a pure income tax, where both wages and the return to capital are taxed. As under the wage tax, Jane's $\$ 100,000$ of wages would be taxed initially, producing a $\$ 30,000$ tax and leaving only $\$ 70,000$ to invest. Unlike under a wage tax, however, her $\$ 7,000$ investment return would also be taxed, producing another $\$ 2,100$ in tax. Thus, her net return under an income tax would be only $\$ 74,900$.

Because of the concentration of capital income in the very wealthiest of households, a tax on labor income only at the individual level cannot realistically replicate the progressivity of the current tax burden under the income tax. Households in the top $1 \%$ earn only about $45 \%$ of their aggregate income from labor. ${ }^{181}$ For those households that adhere to this average, it might be theoretically possible to maintain the same progessivity as today if we simply translated the tax that would otherwise be imposed on capital income (the $\$ 2,100$ in the income tax example above) into higher marginal rates on the labor earnings of these high earners (a tax rate in excess

${ }^{181}$ See Alan B. Krueger, When It Comes to Income Inequality, More Than Just Market Forces Are at Work, N.Y. TIMES, Apr. 4, 2002, at C2. 
of $30 \%$ in the example above). But a return to pre-Reagan high marginal rates is both not politically realistic in the $21^{\text {st }}$ century and not good economic policy in the eyes of most economists. Moreover, for those high-income households that earn very little labor income, such as heirs living off of the return of inherited capital, it would be absolutely impossible to replicate the current progressivity with a tax solely on labor returns. In sum, a wage tax would further shift the tax burden away from the top $1 \%$, which controlled roughly $33 \%$ of the nation's private wealth in $2001,{ }^{182}$ to the middle class.

There is another shortcoming to a wage tax, in particular. A wage tax treats all investments the same on an ex ante basis. Thus, the same $\$ 30,000$ tax (in our wage tax example above) would be paid on Jane's $\$ 100,000$ of wages (leaving $\$ 70,000$ to invest), even if she earns an extraordinary return in excess of what most investors earn on a $\$ 70,000$ investment (which allows her to consume more, after all). If the prevailing investment return for most investors is $10 \%$, but Jane is lucky enough to earn an extraordinary return of $30 \%$ on her investment, she would still pay only the same $\$ 30,000$ tax paid by all others who invested $\$ 70,000$ and earned only $10 \%$. Jane would be able to consume not merely $\$ 77,000$, as would most investors, but $\$ 91,000$ ( $\$ 70,000$ plus $\$ 21,000$ investment return). Most would argue that this unequal treatment is unfair.

A cash-flow consumption tax, in contrast, treats all investments the same on an ex post basis. That is to say, all investments with the same gross return are treated the same because the tax event occurs at the point of consumption. So if John invested only $\$ 60,000$ and earned a total return of $\$ 110,000$ before consuming it, he would be taxed the same as Jane, who invested $\$ 70,000$ and earned a total return of $\$ 110,000$ before consuming it. But a cash-flow consumption tax is simply impossible to implement as a political matter, as it would require the inclusion of borrowed money in the tax base (with a deduction of principal and interest repayments). The average citizen simply will not tolerate the taxation of money borrowed to purchase a home, to pay for higher education, or to make ends meet when catastrophe strikes and the job is lost (even though a sales tax effectively reaches such borrowing). The cash-flow consumption tax is too close in form to the current tax structure, under which borrowed money is not taxed, for the public to equate it with a sales tax rather

182 See Arthur B. Kennickell, A Rolling Tide: Changes in the Distribution of Wealth in the U.S., 1989-2001, http://www.federalreserve.gov/pubs/oss/oss2/papers/ concentration.2001.6.pdf. 
than the current tax system - particularly when it is offered as a replacement for the current system. As a replacement for the current tax system, a tax that includes borrowed money in the tax base is not politically salable to the public. In short, a cash-flow consumption tax is dead on arrival as a realistic alternative, even if marginal rates could be made so progressive at the top as to replicate the current distribution of the tax burden (which is unlikely). ${ }^{183}$

The only remaining consumption tax alternatives are not annual taxes but transaction-based taxes: sales taxes and value added taxes. Neither can accommodate a progressive rate schedule and thus neither can replicate the current progressivity of the income tax.

Some argue fairness norms must be trumped by economic norms in some cases, and decreased taxation or complete exemption of capital income (as compared to labor income), or substitution of a flat-rate sales tax or value added tax for our current hybrid income/consumption tax, is defended chiefly on economic growth grounds today. As the eminent public finance economist Richard Musgrave once wrote, however, "any departure from equity must have clear justification in terms of probable effectiveness with regard to growth, ${ }^{, 184}$ and the economic evidence regarding economic growth is not particularly compelling.

As a matter of history, for example, the evidence appears to be weak. Robert Frank, for example, notes that the "golden age" of high productivity and growth rates in the United States and most of the rest of the industrialized world occurred between the end of WWII and roughly 1973. This era was a time of high marginal rates on the wealthy, a time when a much larger percentage of the aggregate tax burden was contributed by the corporate tax (a tax on capital owned disproportionately by the wealthy), and a time of much less income and wealth inequality than is seen today. Moreover, those countries with greater shares of national income going to the poor and middle classes had higher growth rates. ${ }^{185}$ Freeing the capital income of the

${ }^{183}$ Slemrod and Bakija conclude that a cash-flow consumption tax would simply be too difficult to administer to be an effective replacement for current law. SLEMROD \& BAKIJA, 3d. ed., supra note 69, at 255-56.

${ }^{184}$ Letter from Richard Musgrave to Walter Heller (Oct. 1960), in JOHN F. WitTe, The Politics and Development of The Federal Income Tax 159 (1985). Heller would later become head of President Kennedy's Council of Economic Advisors.

${ }^{185}$ See Robert H. Frank, Progressive Taxation and the Incentive Problem, in Does Atlas Shrug?: The ECONOMIC Consequences of TAXING THE RICH 490, 494 (Joel B. Slemrod ed., 2000); SLEMROD \& BAKIJA, 3d ed., supra note 69, at 114-18. 
wealthy from tax (or taxing it at lower rates than labor income), thereby reducing the progressivity of the tax burden, could accomplish little more than greater income and wealth inequality than we see today ${ }^{186}$ h little or no boost to economic growth. ${ }^{187}$

The argument that reducing taxation of capital income or savings results in increased economic growth assumes that decreased taxation of savings or capital will cause changes in behavior that result in more savings and capital for new investment in new ventures and technologies, which will lead to an expanding economy. But there are several problems with the assumptions in the argument. It assumes that people would react to the tax incentive by actually substituting consumption behavior with saving behavior (called the substitution effect), thereby increasing the percentage of income saved. Those people who save for fixed targets, however, such as $\$ 500,000$ saved by retirement age, or $\$ 50,000$ saved by the time Junior reaches college, could actually save a lower percentage of their income than they did under an income tax that reached savings currently and still reach their targeted savings numbers (called the income effect). The empirical evidence is incomplete regarding the number of "target savers" out there, ${ }^{188}$ but it appears to be high. The evidence seems to indicate that the vast middle class contains many so-called life-cycle savers: target savers who attempt to save just enough to meet contemplated future consumption needs. ${ }^{189}$ Indeed, the savings rate

${ }^{186}$ See David Cay Johnston, More Get Rich and Pay Less in Taxes, N.Y. TIMES, Feb. 7, 2002, at A22 (citing NYU economics professor Edward N. Wolff's conclusion that "wealth in America is more highly concentrated today than at any time since 1929."). See generally Geier, supra note 176, at 110-19 (documenting the trend toward greater concentration of after-tax income and wealth in the top $1 \%$ ).

187 See Hal R. Varian, Perhaps It's Time for a Thorough Tax Overhaul, But the Question Is, What Should Any Reconfigured System Look Like?, N.Y. TIMES, May 5, 2005, at C2 ("Some economists have claimed that the changes in 1986 increased the economy's growth rate by as much as 1 percent in the years immediately afterward."). One of the most dramatic changes made in that act was the repeal of the reduced tax rate on capital gain, taxing it at the same rate as the taxpayer's ordinary income. That change meant that the highest capital gains tax rate was increased from $20 \%$ to $28 \%$, the highest ordinary income tax rate. Unfortunately, only five years later when the top tax rate on ordinary income was raised to $31 \%$, the top tax rate on capital gains was left at $28 \%$, reintroducing favoritism based on source of income.

188 "Economic theory is completely silent on the question of which of these two opposing effects will dominate. The case for the conventional (supply side) position must therefore be made on empirical grounds." Frank, supra note 185, at 491.

${ }^{189}$ See Carroll, supra note 27, at 465-66. The super rich, on the other hand, have very high savings rates - additional evidence that freeing all savings (or capital returns) from current taxation would further reduce progressivity and increase after- 
(the percentage of income saved) has consistently fallen over the last twenty years, the very time period during which tax subsidies for savings, which were broadly introduced in the early 1980s, increased substantially. ${ }^{190}$ This correlation indirectly supports the notion that there are a lot of target savers out there for whom reduced taxation of savings results in a decreased percentage of income saved.

Moreover, the United States is not a closed economy; capital not supplied by American savings has been readily supplied by foreigners. In other words, there does not appear to be a capital crunch in the United States that is slowing economic growth. If anything, there appears to be more money sloshing around looking for good investments than available investment opportunities" saving glut," in the words of Ben Bernanke, Chairman of the Board of Governors of the Federal Reserve. ${ }^{192}$ Many believe this excess capital is contributing to the worldwide run-up in housing prices, for example, as the capital looks for somewhere to go. ${ }^{193}$

Finally, tax incentives or disincentives may simply have very little effect on savings behavior in any event.

Behavioral economists admit to not knowing at all why people save. The decision can be an amalgam of inability to delay gratification, hyperbolic discount rates (which is another way of saying the same thing, because it means that a person would require unreasonably high rates of return to make it worthwhile to save and thus delay immediate gratification), general personality traits, even the role of shame. Since middle class savers already enjoy... consumption tax treatment for the bulk of their savings, enacting a pure consumption tax might do little more than provide inefficient windfall benefits to the top $1 \%$ for the savings behavior that they would have engaged in anyway. ${ }^{194}$

tax income and wealth inequality.

190 See SLEMROD \& BAKIJA, 3d ed., supra note 69, at 129-30.

191 See, e.g., Floyd Norris, Too Much Capital: Why It Is Getting Harder to Find a Good Investment, N.Y. TIMES, Mar. 25, 2005, at C1.

192 See, e.g., Jon E. Hilsenrath \& Patrick Barta, Amid Low Rates, Home Prices Rise Across the Global Village, WALL ST. J., June 16, 2005, at A1 (also quoting another commentator as saying, "[t]here is a tremendous amount of money floating around looking to invest").

${ }^{193}$ See id.

${ }^{194}$ Geier, supra note 176, at 147. 
For example, recent work by behavioral economists show a significant increase in savings in the lower and middle classes simply by changing the default rules for enrolling in savings plans associated with employment. While the typical employer requires the employee to opt into these plans, those who automatically enroll employees and require them to opt out if they do not wish to participate see dramatically increased savings rates among employees. "In one study ..., shifting to automatic enrollment raised participation among poorer workers from just over $10 \%$ to over $80 \% . " 195$ As the Economist Magazine suggests: "Rather than focusing on tax incentives, recent economic research suggests politicians ought to look harder at what stops people saving."196

Joel Slemrod and Jon Bakija, after surveying the literature, concluded that the economic benefits from consumption taxation (or freeing capital income from tax) would not likely be great.

The weight of the evidence suggests private saving is probably not very responsive to the after-tax rate of return. The bottom line is that switching to a consumption tax does not guarantee a big boost in saving and investment-our best guess is that at most there would be only a small increase. Because there are more direct ways to increase national saving (for example, increasing the budget surplus), the likely but not assured prospect of a somewhat higher saving rate does not appear to be, by itself, a reason to undertake a wholesale transformation of the tax system. ${ }^{197}$

Finally, much of the economic-growth punch, such as it is, that could come from a switch to a clean consumption tax would likely arise from the one-time wealth tax effectively imposed on accumulated wealth at the time of the transition. For example, under

${ }^{195}$ The Shift Away from Thrift, ECONOMIST, Apr. 9, 2005, at 60.
${ }^{196}$ Id.

197 SLEMROD \& BAKIJA, 2d ed., supra note 36, at 235. These conclusions continue in the third edition of their book, where they say: "If empirical evidence showed a strong positive relationship between saving and its after-tax rate of return, the economic costs of our income tax and the economic benefits of switching to a consumption tax could be quite large. However, the available evidence does not readily reveal any such relationship." SLEMORD \& BAKIJA, 3d ed., supra note 69, at 129; see also id. at 212-14 (notably updating the second edition language quoted above that refers to "increasing the budget surplus" to "reducing the budget deficit") and 265-71 (concluding that "switching to a consumption tax is unlikely to increase permanently our rate of growth at all"). 
a cash-flow consumption tax for businesses, depreciation deductions relating to old wealth would simply disappear (only new investments would be expensed). Moreover, consumption of previously saved amounts by the elderly in retirement would trigger a second tax on old wealth under a cash-flow consumption tax or sales tax that would not be paid under current law. But CEOs of fortune 500 companies about to lose billions in depreciation deductions and the elderly who consume from previously taxed savings could be expected to argue vociferously in the political arena for transition relief, thus negating whatever meager boost to economic growth might otherwise arise from the switch. ${ }^{198}$

Three other commonly cited arguments for a reduced rate on capital gains are the bunching problem, the inflation gain problem, and the lock-in effect. With respect to the first, the argument is that, because gain is realized entirely in one year, some of that gain might be taxed at a higher marginal rate than might have occurred had the gain been taxed as it accrued over time. But the deferral of gain recognition under the realization principle can be more valuable because of the time value of money than any detriment arising because of bunching. This is particularly true if the taxpayer was in the highest marginal rate bracket over the entire period of gain accrual (and recall that capital gain is highly concentrated in the wealthier households). Finally, the cure for this problem, if it is a problem, would be income averaging, a provision that was repealed in 1986 with the general flattening of the rate structure. A uniform rate reduction for all capital gain does not seem warranted on this ground.

With respect to inflation gain, any inflation adjustment needs to affect not only gain on "capital" assets but recognized gain on all assets as well as other tax attributes affected by inflation, such as depreciation and net operating loss carryovers. Moreover, a fixed lower rate for all capital gain as an inflation adjustor is extremely crude, applicable whether the asset has been held a year and a day or twenty years and regardless of the inflation rate over time. As I (and my co-authors) explain elsewhere:

[T]here is a "correct" technical solution to the inflation problem, which is to index the basis of all assets according to a formula:

new basis $=$ previous basis $\mathrm{x}$ price index at end of year price index at beginning of year

${ }^{198}$ See SLEMROD \& BAKIJA, 3d. ed., supra note 69, at 215. 
Although indexing the basis of property has intellectual support in some academic, business, and investment circles, there are practical and political obstacles. One is that it is complex; not only assets but also depreciation deductions, NOL carryovers, capital loss carryovers, etc. - anything that affects how the tax base is measured over time - would have to be indexed. Another is that, if the basis of assets were indexed for inflation, then the basis (principal) of debt instruments must also be indexed, since they are assets owned by lenders. Borrowers enjoy a benefit in times of inflation, because they are repaying debt with dollars that aren't worth as much as when they borrowed them. When debt basis is increased, a portion of what is nominally called "interest" on the debt really becomes a return of "principal."

To illustrate, assume that Kunal borrows $\$ 1,000$ for one year at $10 \%$ interest on January 1 and that there is $5 \%$ inflation during the year. At the end of the year, the $\$ 1,000$ of principal which the lender is entitled to receive back is worth only $\$ 950$ $(\$ 1,000$ less $[.05 \times \$ 1,000])$. If the debt basis, or principal, is increased to account for this inflation, then the $\$ 1,000$ of nominal principal and the $\$ 100$ nominal interest $(\$ 1,100$ total) paid by Kunal at year end will be recharacterized for tax purposes as $\$ 1,050$ of principal $(\$ 1,000 \times 1.05)$ and $\$ 50$ of interest $(\$ 1,100$ total). Thus, indexing debt for inflation would confer a tax advantage on banks (which would be entitled to "exclude," as return of principal, what is called "interest" in the loan documents). On the other hand, business and investment debtors... would be denied a deduction for the portion of the nominal interest recharacterized as "principal." Because the losers far outnumber the winners, indexing debt is such a "hard sell" politically that no U.S. politician has even tried.

Some have proposed indexing the basis of all assets except debt principal. This would, however, distort investment decisions by allowing well-informed taxpayers to engage in tax arbitrage. For example, assume that Kunal, whose marginal income is taxed in the $35 \%$ bracket, borrows $\$ 1,000$ at $10 \%$ interest and purchases a non-depreciable investment asset for $\$ 1,000$. A year later, he sells the asset for $\$ 1,100$ and 
uses the sales proceeds to pay the $\$ 1,000$ of principal and $\$ 100$ of interest owed on the loan. Kunal hasn't realized a dime of economic profit from his debt-financed investment, and his tax results reflect this: he incurs $\$ 35$ of tax on this $\$ 100$ gain and saves $\$ 35$ of tax from his $\$ 100$ interest deduction, thus leaving him with zero tax liability. Now, however, assume that there was $5 \%$ inflation during the year and that asset basis, but not interest or debt basis, is indexed. Kunal's asset basis would be adjusted to $\$ 1,050$ ( $\$ 1,000$ cost $\times 1.05)$, his sale gain would be only $\$ 50$ ( $\$ 1,100$ AR less $\$ 1,050 \mathrm{AB})$, and the tax on this gain would be $\$ 17.50$ ( $\$ 50 \times .35$ ). But Kunal would also deduct a $\$ 100$ (unindexed) interest payment, resulting in $\$ 35$ of tax savings, so that he would have $\$ 17.50$ of tax savings in excess of his tax liability ( $\$ 35$ tax saved less $\$ 17.50$ tax owed). In other words, with indexing that did not affect debt basis or interest, Kunal would come out $\$ 17.50$ ahead after tax even though his debt-financed investment produced an economic wash. More broadly, indexing limited in this way would encourage taxpayers to make debt-financed investments that are economically pointless, or sub-marginal, in order to produce tax arbitrage gains like Kunal's, i.e., it would be an economically inefficient change in the law.

Because of these problems and because much, if not most, long-term capital gain property is acquired by borrowing, the best practical solution to the inflation problem may be to refrain from indexing. The overstatement of gain on sales of investment assets would then be offset (perhaps more than offset) by the investor's deduction of overstated interest and the advantage of deferring tax on the investment gain until sale. ${ }^{199}$

Recall that I recommended earlier that the gain recognized on the sale of the primary personal residence be reduced for inflation gain so that only the gain in excess of inflation gain is taxed (to the extent not protected by the Nondiscretionary Deduction). Because I concurrently recommended that interest paid on home mortgage debt no longer be deducted as such (to be replaced for homeowners with a shelter component in their Nondiscretionary Deduction computed by reference to the median rental cost of single-family homes for various

199 DodGE ET AL., supra note 4, at 737-38. 
household sizes, median property taxes, and median utility costs), there would be no tax arbitrage problem in that context. Moreover, since inflation adjustments would be limited to that single context, it would not be administratively difficult to implement (a table on the home sale gain form would easily take care of the issue) and yet would also comply with President Bush's mandate that the ownership of homes continue to be favored over the ownership of other, competing assets.

A final argument often made in defense of a lower tax rate on capital gains is the so-called lock-in effect: that the tax on sale of capital assets artificially inhibits the efficient allocation of investment capital across the economy. I and my co-authors respond to that argument elsewhere as follows:

The lock-in (or economic efficiency) argument would be persuasive only to the extent that it could be shown that particular property could be put to more productive use if owned by a taxpayer different from the current owner, and the current owner does not sell to the more efficient user solely because of the tax that would be due on sale. This argument is not persuasive with respect to most Capital Assets, such as stocks, bonds, and collectibles. It might have some force with respect to real estate because of the unique nature of each parcel, where some taxpayers may be in a better position than others to develop the property. But ... a large swath of business and investment real estate is exchanged in kind to take advantage of deferral under $\S 1031$.

Moreover, a more significant cause of the lock-in effect for any remaining gain is $\S 1014$, which permanently exempts unrealized gains on property owned at death and thereby encourages taxpayers to hold appreciated property until their demise in order to transfer it to their heirs with the gain laundered out.

The second problem with the "capital mobility" argument is that it suggests that any tax benefit on liquidating investments should be conditioned on reinvesting the proceeds from the sale of the investment. The capital-mobility rationale is entirely lost with respect to capital gain realized in order to finance consumption. There is currently no reinvestment 
requirement, however $\ldots{ }^{200}$

In sum, the arguments for moving away from the original purpose for enacting an income tax - to tax capital income and not merely consumption - are not persuasive. They are clearly inconsistent with the premises described in this article that the "ideal" tax base should focus not on the source of income, whether from labor or capital, but rather on whether the income can fairly be considered to be "discretionary" or "nondiscretionary."

\section{GRATUITOUS RECEIPTS}

The Civil War income tax treated gratuitous receipts as "income." But neither the 1894 income tax that was held unconstitutional in Pollack v. Farmers' Loan \& Trust $\mathrm{Co}^{201}$ nor the first income tax enacted in 1913 after ratification of the Sixteenth Amendment taxed gratuitous receipts as "income." 202 There is no legislative history informing us of the reasoning behind the change in heart between the mid- $19^{\text {th }}$ century tax and the later taxes, but "enough is known to permit some informed speculation., ${ }^{203}$

By the turn of the twentieth century, both the law of trust accounting and business or financial accounting had developed notions of what constitutes "income" for their separate purposes, and these notions may have informed early thinking about what the term "income" should mean within the context of a tax on "income." By the time of Henry Simons's path-breaking work in 1938 describing the contours of the term "income" for tax purposes, under which gratuitous receipts could be considered "income" to the donee, the estate and gift taxes were in place and perhaps provided an independent reason for excluding gratuitous receipts under the income tax. ${ }^{204}$

It has never been generally held that a dollar taxed to another somewhere in the economy cannot be taxed when transferred again to a different taxpayer. When I earn wages (includable in my gross

Id. at $739-40$.

201157 U.S. 429 (1895).

${ }^{202}$ Indeed, current law still allows exclusion from gross income of all receipts acquired "by gift, bequest, devise, or inheritance." I.R.C. \$ 102(a).

${ }^{203}$ DODGE ET AL., supra note 4, at 155.

${ }^{204}$ Id. at $155-57$. 
income under sections 61(a)(1)) and then take some of my after-tax dollars and pay my window washer for washing my windows (a nondeductible personal expense to me), my window washer cannot successfully argue that his receipt should not be taxed because the dollars were once previously taxed to me. And this should remain true even in the case of a mere transfer, without my windows being washed. That is to say, ever since Henry Simons's refinement of what the term "income" ought to mean for tax purposes, each taxpayer is generally viewed independently, where the same dollar can result in multiple wealth accessions (and thus "income") as after-tax amounts are transferred from taxpayer to taxpayer. After Simons, the relevant question generally is: To what extent has the taxpayer been enriched?

Nevertheless, as noted above, the unlimited gift exclusion has continued, most likely because of the concomitant existence of the wealth transfer taxes. Under current law, however, the estate and generation-skipping taxes are scheduled to be fully repealed in 2010 , only to be resurrected in full force in 2011 without further action on the part of Congress. Even with the temporary repeal of these taxes in 2011, however, the gift tax was continued for two reasons. First, retention of the gift tax ensured that the temporary, one-year repeal of the estate tax did not result in effective repeal for an entire generation. ${ }^{205}$ Second, even with permanent repeal of the estate and generation-skipping taxes, retention of the gift tax would ensure that investment property is not shifted without tax cost among family members in order to have the subsequent investment income taxed at the lowest family member rate while effectively keeping it "all in the family." In other words, the gift tax would act as a backup to protect the integrity of the progressive rate structure of the income tax, as do both section $1(\mathrm{~g})$ (the so-called kiddie tax) and the common-law, assignment-of-income doctrine. ${ }^{206}$

President Bush's current proposal to make permanent the repeal of the estate and generation-skipping taxes would continue the gift tax

205 See John Buckley, Estate Tax Repeal: More Losers Than Winners, 106 TAx Notes 833, 833 (2005) (noting that, in the absence of a gift tax, "even a very short period during which [gift tax] repeal was in effect would effectively repeal the estate tax for a generation. Individuals could simply gift the bulk of their assets to their children during the period of repeal. Retention of the gift tax effectively forecloses that opportunity.").

${ }^{206}$ See Jonathan G. Blattmachr \& Mitchell M. Gans, Wealth Transfer Tax Repeal: Some Thoughts on Policy and Planning, 90 TAX NOTEs 393 (2001) (alerting Congress to the need to retain the gift tax as a backup to the income tax, even with permanent repeal of the estate tax). 
for lifetime gifts in excess of $\$ 1$ million. ${ }^{207}$ Current section 1014, allowing a fair market value basis for all property transferred at death, would be replaced by proposed section 1022 , which would require a carryover basis, with two adjustments. First, the basis of any appreciated property could be increased by up to $\$ 1.3$ million (indexed for inflation) "for free," not to exceed the property's fair market value. Second, property transferred to a surviving spouse could be increased "for free" by up to an additional $\$ 3$ million (indexed for inflation), not to exceed the property's fair market value.

The fairness value espoused in this article - that income available for discretionary use ought to be taxed - means that gratuitous receipts should be included in the gross income of the recipient to the extent exceeding an administratively feasible de minimis floor of, say, $\$ 25,000$ per year. ${ }^{203}$ Transfers to spouses would continue to be excluded in full, as they are under current section 1041(b)(1). To the extent that an includable receipt is offset by the taxpayer's Nondiscretionary Deduction, it will be protected from taxation, but to the extent that the includable receipt exceeds the taxpayer's Nondiscretionary Deduction (and other deductions), it ought to be taxed. There is no persuasive reason why the $\$ 150,000$ in wages of a hardworking taxpayer ought to be taxed to the extent exceeding the Nondiscretionary Deduction and other allowable deductions, while the taxpayer who receives "gifts" of $\$ 150,000$ has no tax liability.

If section 102 were amended in this fashion, the estate, gift, and generation-skipping transfer taxes could each be permanently repealed. Whether the transfer is received during the donor's life or at his or her death, the recipient of an in-kind gift could take a fair market value basis, as under current section 1014 only for transfers at death, to the extent that the property is included in gross income. The carryover basis rule in section 1015 currently applicable to all inter vivos gifts would apply only to those in-kind gifts (whether at death or during life) excluded under the de minimis rule. ${ }^{209}$ The well-

${ }^{207}$ See, e.g., Karen C. Burke, Estate Tax Repeal and the Budget Process, 104 TAx NOTES 1049 (2004) (confirming details of the proposal but questioning its viability).

${ }^{208}$ As an outlay not in pursuit of income production, the transfer would be nondeductible to the transferor.

${ }^{209}$ For example, assume that the only gift received by the recipient in a tax year is a gift of property in kind with a fair market value of $\$ 25,000$ and a basis in the hands of the donor of $\$ 10,000$. Since the gift would be excludable under the de minimis rule, the recipient would take a $\$ 10,000$ carryover basis in the property. If, on the other hand, the recipient receives property with a fair market value of $\$ 1$ million and a basis 
documented difficulties of the proposed carryover basis rule in section 1022 could thus be avoided. In addition, Congress could continue favored treatment for certain assets under an income-inclusion system, such as the transfer of a working farm to family members, if desired. Moreover, if the underlying value of the current estate tax is to discourage undue concentrations of wealth (and thus power), an income-inclusion system would encourage breaking up a large estate among as large a number of beneficiaries as possible (to take advantage of the multiple Nondiscretionary Deductions of the recipients) more effectively than would a single estate tax imposed on the donor. Finally, the incentive for transfers to charities would be continued because receipts by qualified tax-exempt organizations would be excluded by the organization and deducted by the donor to the extent allowed under section 170.

At least two potential difficulties would need to be addressed, but neither appears insurmountable. Support received by a minor child is not currently includable in gross income. ${ }^{210}$ Since these amounts are presumably "nondiscretionary," this current treatment is consistent with the values underlying this article. But since both "support" characterization and "gift" characterization results in "no inclusion" under current law, repeal of the unlimited gift exclusion would require, for the first time, differentiating excludable "support" from potentially includable "gifts." Treasury would need to draft regulations under section 102 drawing the line between the two, but the line should not be terribly difficult to draw in most instances. Excludable "support" should include all in-kind transfers of such consumption items and services as food, clothing, housing, medical care, entertainment, and education of the minor child. Similar provision by a parent to a dependent child enrolled in full-time higher education would also be defensible. Transfers of cash and investment property, on the other hand, should not qualify as "support."

in the hands of the donor of $\$ 250,000$, the recipient would include the full $\$ 1$ million value (since it exceeds the de minimis amount) and would take a basis of $\$ 1$ million in the property. In neither case would the transfer be considered a realization event for the donor with respect to any built-in gain or loss.

210 See, e.g., Gould v. Gould, 245 U.S. 151 (1917). Though Gould held that a divorcee's receipt of support from her ex-husband was not "income," the Court's rationale would equally apply to transfers to minor children. (Transfers between divorcing spouses are now governed by sections 71 and 1041.) See generally DoDGE ET AL, supra note 4, at 188-91 (discussing the common-law "support" exclusion). 
As identified by a recent report by a Task Force appointed by the American Bar Association Tax Section, ${ }^{21}$ another difficulty that would need to be addressed is the transfer to a trust. ${ }^{212}$ Under current law, a transfer of cash or property to a trust is treated as an excludable "gift," and the trust corpus is also excludable when received by the ultimate beneficiary. Subchapter J of the Code prescribes the rules pertaining to the taxation of income earned by the trust on its assets. Very generally speaking, retained trust income is taxed to the trust itself under section 1(e), while previously untaxed distributed trust income is taxed to the beneficiary.

With repeal of the unlimited gift exclusion for direct transfers to individuals, a decision would have to be made regarding whether similar transfers to trusts ought to be immediately includable by the trust. If it were not - if, instead, the taxation of the corpus is delayed until received by the ultimate beneficiary - there would be a tax incentive (deferral) to make transfers via trusts rather than directly. If the problem with taxing the trust in the year of trust receipt is lack of liquidity, perhaps deferral could be granted but only at the cost of an interest charge to take account of the time value of deferral. ${ }^{213}$

\section{CONCLUSION}

The distinction that I draw between discretionary and nondiscretionary income has resonance not only in rationalizing current law but for reforming and simplifying it. Our current system evidences a consensus that not all consumption ought to be taxed (as

${ }^{211}$ See TASK Force on Federal Wealth Transfer TaXes, A.B.A., RePORT ON REForm of Federal Wealth TRANSFer TAXES, reprinted in 58 TAX LAw. 93 (2004) [hereinafter TASK FORCE]. In Appendix A, the Task Force examined and reported on three possible modes of wealth transfer taxation: (1) an estate, gift, and generation-skipping transfer tax imposed on the donor, (2) a lifetime accretions tax, separate from the income tax, imposed on donees, and (3) an income inclusion for the donee under the existing income tax. Id. at 279. Consistent with the third option, the unlimited exclusion for life insurance proceeds received on account of the death of the insured under section 101(a)(1) should also be repealed.

On the option of including gratuitous receipts, see also Joseph M. Dodge, Beyond Estate and Gift Tax Reform: Including Gifts and Bequests in Income, 91 HARV. L. REV. 1177 (1978); Marjorie E. Kornhauser, The Constitutional Meaning of Income and the Income Taxation of Gifts, 25 CONN. L. REV. 1 (1992).

${ }^{212}$ See TASK FORCE, supra note 211, at 293-94.

${ }^{213}$ Cf. I.R.C. $\$ 1291$ (imposing a similar interest charge on Passive Foreign Investment Company (PFIC) income to the extent immediate inclusion on the PFIC owner's tax return is deferred until actual distribution of PFIC earnings or sale of the PFIC stock). 
it would under a pure consumption tax), that not all savings of the middle class for retirement and other specified needs should be currently taxed (as they would under a pure income tax), and that not all savings of the very wealthy should avoid current taxation (as they would under a pure consumption tax). The lines that demarcate our current hybrid income/consumption tax recognize that the issue is not so much whether the outlay at issue qualifies as "consumption" or "savings" but rather whether the particular consumption or savings at issue can fairly be considered "nondiscretionary," in which case it would not fairly be available to the fisc, or "discretionary," and thus fair game.

This insight points to three significant reforms: (1) creating a single Nondiscretionary Deduction (with component parts based on median outlays for various nondiscretionary costs for households of various sizes) that would replace the Standard Deduction, the Personal and Dependent Exemption Deductions, the Child Tax Credit, the Qualified Residence Interest Deduction, the Deduction for State and Local Income and Property Taxes, and perhaps the Dependent Care Credit and the Hope and Lifetime Learning Credits, (2) taxing labor and capital income at the same (progressive) rates, and (3) repealing the unlimited gift exclusion (with concomitant repeal of the estate, gift, and generation-skipping taxes). These reforms would also broaden the base and thus may allow across-theboard tax rate reductions, though it would be imperative to retain at least a mildly progressive rate structure if the Nondiscretionary Deduction is to be a single deduction for all similarly situated taxpayers, since each tranche of additional income contains everlarger percentages of income available for discretionary use. Finally, an additional benefit of these reforms is that they would allow for repeal of the AMT. More important, however, the net effect of these changes would be a fairer and simpler tax system that empirically took into account the reasonably unavoidable costs of living. 